\title{
Description of Physical
}

Environment and of

Strip-Mining Operations in

Parts of Beaver Creek Basin Kentucky

GEOLOGICAL SURVEY PROFESSIONAL PAPER 427-A

Prepared in cooperation with the Commonwealth of Kentucky and with Federal agencies

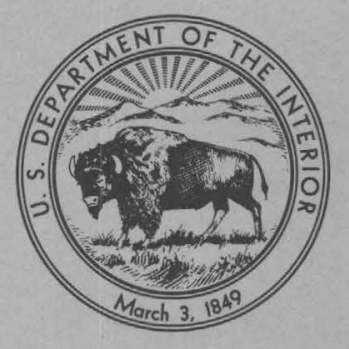





\section{Description of Physical}

\section{Environment and of}

Strip-Mining Operations in

Parts of Beaver Creek Basin

\section{Kentucky}

By JOHN J. MUSSER

HYDROLOGIC INFLUENCES OF STRIP MINING

GEOLOGICAL SURVEY PROFESSIONAL PAPER 427-A

Prepared in cooperation with the Commonwealth

of Kentucky and with Federal agencies

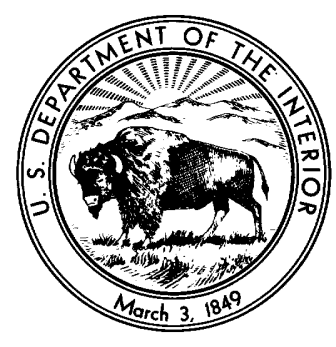




\section{UNITED STATES DEPARTMENT OF THE INTERIOR}

STEWART L. UDALL, Secretary

GEOLOGIGAL SURVEY

Thomas B. Nolan, Director

For sale by the Superintendent of Documents, U.S. Government Printing Office Washington, D.C. 20402 


\section{CONTENTS}

\begin{abstract}
Introduction

ysical description of Beaver Creek basin...........

Topography and drainage..........

Geology -

Stratigraphy ......................

Strata below the main cliff-forming sandstone...

Main cliff-forming sandstone

Strata above the main cliff-forming sandstone

Coal seam in Cane Branch basin

Unconsolidated rocks.........................

Spoil bank.

Talus piles.......

Fluvial deposits

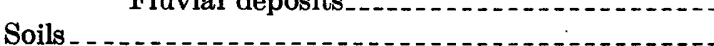

General description . . .

Enders series_...............

Jefferson series

Tilsit series.
\end{abstract}

\begin{tabular}{|c|c|}
\hline se & \\
\hline A1 & Physical description of Beaver Creek basin-Continued \\
\hline 2 & Soils-Continued \\
\hline 3 & Hartsells series . \\
\hline 3 & Wellston series \\
\hline 6 & Muskingum series $\ldots \ldots$ \\
\hline 6 & Johnsburg series..... \\
\hline & Stendal series . . . \\
\hline 6 & Stony colluvial land \\
\hline 7 & - \\
\hline & 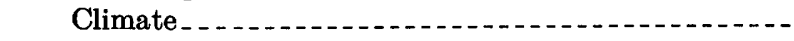 \\
\hline 8 & Hydrologic environment \\
\hline 11 & retation \\
\hline 11 & cover types \\
\hline 11 & ssity \\
\hline 14 & nd methods \\
\hline 14 & Mining before 1955 \\
\hline 15 & Mining a \\
\hline 15 & the first operator $(1955-56) \ldots$ \\
\hline 16 & the second operator $(1957-59)$. \\
\hline 16 & d operator $(1958-59)$ \\
\hline 17 & Activities of the fourth operator $(1960)$ \\
\hline
\end{tabular}

\section{ILLUSTRATIONS}

\section{[Plates are in pocket]}

Plate 1. Topographic map of Cane Branch and West Fork Cane Branch study areas.

2. Topographic map of Helton Branch study area.

3. Map showing coal mining and prospecting sites.

4. Map of Cane Branch and West Fork Cane Branch study areas showing soil types.

5. Map of Helton Branch study area showing soil types.

6. Map of Cane Branch and West Fork Cane Branch study areas showing forest types.

7. Map of Helton Branch study area showing forest types.

Frgure 1. Map of part of Beaver Creek basin

2. Area-elevation curves of study areas

3. Profile traversing West Fork Cane Branch and Cane Branch study areas

4. Profile traversing Helton Branch study area

5. Stream-channel profiles............

6. Extent of coal and cliff-forming sandstone of Pennsylvanian age

7. Columnar sections of rocks of Pennsylvanian age

8. Generalized sections of rocks of Pennsylvanian age

9. The coal seam in the Cane Branch basin

10. The highwall on the southwest side of the Cane Branch basin

11. The highwall on the northeast side of the Cane Branch basin

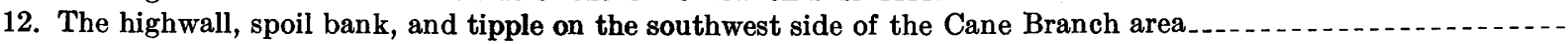

13. Strip mining along northeast side of Cane Branch area

14. The highwall, strip pit, and spoil bank in the Cane Branch area

Page

\section{TABLES}

Page

A16

2. Distribution of forest-cover types in Cane Branch, West Fork Cane Branch, and Helton Branch study areas ..-
3. Distribution of stand-size classes in Cane Branch, West Fork Cane Branch, and Helton Branch study areas

4. Acres of stand-size classes by forest-cover types in Cane Branch, West Fork Cane Branch, and Helton Branch study areas........

5. Stocking density in Cane Branch and Helton Branch study areas . . 



\title{
HYDROLOGIC INFLUENCES OF STRIP MINING
}

\section{DESGRIPTION OF PHYSICAL ENVIRONMENT AND OF STRIP-MINING OPERATIONS IN PARTS OF BEAVER GREEK BASIN, KENTUCKY}

\author{
By John J. Musser
}

\begin{abstract}
An investigation of the effects of strip mining for coal on the hydrology of parts of the Beaver Creek basin, McCreary County, Ky., was begun by several State and Federal agencies in 1955. This report describes the topography, drainage, geology, soils, climate, hydrologic environment, and forest vegetation of the study areas and gives a history and description of the mining. The following study areas are included: (1) The Cane Branch basin, in which there has been mining; (2) the Helton Branch basin, in which there has been no mining and which is reasonably similar to the Cane Branch basin in physical characteristics; and (3) the West Fork Cane Branch basin, in which there has been some prospecting.

The bedrock of the Beaver Creek basin has been eroded by streams to form a maturely dissected, irregular land surface with narrow, winding ridges and deep, steep-sided, narrow valleys. The drainage area of each study area, in square miles, is as follows: Helton Branch, 0.85; Cane Branch, 0.67; and West Fork Cane Branch, a major tributary to Cane Branch, 0.26. Profiles of the steep stream channels and area-elevation curves of the land slopes show that the study areas are similar topographically. The Helton Branch channel has a bedrock floor. Numerous reaches of the Cane and West Fork Cane Branch channel floors are composed of sediment deposits.

The stratigraphic section is divided into three parts, as follows: (1) The strata below the main cliff-forming sandstone that consist mostly of siltstone and claystone; (2) the main cliffforming sandstone that makes the steep valley walls; and (3) the strata above the main cliff-forming sandstone that consist of sandstone, siltstone, claystone, and the Barren Fork coal seam in the Cane Branch and West Fork Cane Branch areas and mostly of sandstone in the Helton Branch area.

The spoil banks in the Cane Branch basin are composed of a heterogeneous mixture of sandstone, siltstone, claystone, soil, and water-soluble sulfur compounds. Downstream from the spoil banks, the stream beds and the lower flood plains are composed of fluvial deposits consisting predominantly of clay and silt-size particles that were derived from the spoil banks. In the Helton Branch basin, fluvial deposits consist of sand- to boulder-size fragiments, and in the West Fork Cane. Branch basin these deposits consist of silt- to boulder-size fragments.

Several great soil groups occur within the study areas, including the Red-Yellow Podzolic group, the Planosol group, and the Alluvial group. The main soil series present are the Muskingum, Hartsells, Wellston, Johnsburg, Tilsit, and Enders, which have
\end{abstract}

formed from parent sandstone, siltstone, and claystone beds. The hydrologic classification of soils indicates that the Helton and Cane Branch study areas are similar in terms of potential runoff, insofar as the soils are concerned.

The climate of southeastern Kentucky is virtually continental in character. The temperature ranges annually from about 5 to $100^{\circ} \mathrm{F}$. The mean annual precipitation is 46 inches. Thunderstorms are common during the spring and summer months. The mean annual snowfall is about 11 inches. Annual runoff averages about 22 inches. Cane and Helton Branches are perennial streams and rarely reach zero flow. West Fork Cane Branch is an intermittent stream and is dry for long periods in the summer and fall.

Chemical weathering has produced the gentle slopes in the uplands of the study areas, and physical weathering has resulted in the formation of the steep valley wails.

The forest vegetation of the study areas consists of stands of pines and oaks on the ridges and of stands of hardwoods and hemlocks in the coves and bottom lands. There are some differences in the percentages of the various forest types in the study areas, but the total percentages of types based on environmental conditions are similar. The Helton Branch area has a larger number of stems per acre than the Cane Branch area.

From 1955 to 1960 , four phases of prospecting and mining took place in the Cane and West Fork Cane Branch study areas. From May 1955 to April 1956, the Barren Fork coal seam was strip mined in the southwest side of the Cane Branch area. After mining was completed, the mine operator leveled the spoil bank resulting from the operation and cleared two ditches to allow drainage into Cane Branch.

From October 1957 to January 1959, a second operator drift mined the coal seam in the highwall on the southwest side of the Cane Branch area. Acid water was frequently pumped from the drift mine into Cane Branch during the mining operation.

From the fall of 1958 to August 1959, a third operator strip mined coal in the northeast side of the Cane Branch area. After mining, the new spoil bank was leveled and a ditch cleared to allow drainage into Cane Branch.

During February and March 1960, a fourth operator, in prospecting for coal along the divide between the Cane and West Fork Cane Branch basins, built a small spoil bank in each of these basins. No coal was mined in the areas during this activity. 


\section{INTRODUCTION}

The advent of modern earthmoving equipment has made possible an upsurge of activity in the strip mining of coal. Many areas in which strip mining with older equipment was marginal or uneconomical may now be mined profitably by this method. Strip mining can drastically disturb the face of the land, and it has become a matter of increasing concern to all people who are interested in the conservation of soil and water resources.

The purpose of the investigations described in this report is to record the effects of strip mining upon as many of the affected natural resources in a watershed as possible. The study will extend over a period of years so that the total import of the effects may be assessed.

The processes and resources that were disturbed and altered by strip mining include vegetation, surfacewater and ground-water runoff, chemical quality of water, erosion of land surface and movement of sediment in stream channels, fish population, and fauna on the stream bottoms.

Much of the early planning for this study was done by the U.S. Forest Service because of the need for factual data on which to base a policy regarding strip mining in National Forest lands. The cooperation of other Federal and State agencies which are interested in the problems created by strip mining was obtained, and the Work Group Committee was formed. The following agencies supported this study: U.S. Forest Service; U.S. Army, Corps of Engineers; U.S. Fish and Wildlife Service; U.S. Soil Conservation Service; U.S. Bureau of Mines; U.S. Geological Survey; Ohio River Valley Water Sanitation Commission; Kentucky Department of Economic Development; Kentucky Department of Fish and Wildlife Resources; Kentucky Geological Survey; Kentucky Strip Mining and Reclamation Commission; Kentucky Division of Flood Control and Water Usage; Kentucky Water Pollution Control Commission.

Individuals from these organizations constitute the Work Group Committee, which supervises the study and divides the collecting and interpreting of data among the interested agencies. The major types of work performed by each agency, except the U.S. Geological Survey, are as follows: (1) Forest-vegetation and hydrologic-condition surveys by the U.S. Forest Service; (2) surveys to estimate the amount of sediment entering Lake Cumberland from the Beaver Creek basin by the U.S. Army, Corps of Engineers; (3) soil surveys of the study areas and estimates of the amount of sheet erosion by the U.S. Soil Conservation Service; (4) collection of data on mining methods and mining history by the U.S. Bureau of Mines; (5) collection of data on the fish population in the upper reaches of the Beaver Creek basin by the U.S. Fish and Wildlife Service; (6) collection of data on the aquatic bottom-dwelling organisms by the Kentucky Department of Fish and Wildlife Resources.

The U.S. Geological Survey, through financial cooperation with the other Federal and State agencies, collected the hydrologic data for the study areas. These data included the amount of precipitation and streamflow, the quality and movement of ground water, the chemical quality of streamflow, the erosion, transportation, and deposition of sediment, and the changes in the channel geometry. The establishment of seedlings upon spoil banks and the effect of mine drainage upon the growth rates of selected trees were also studied by the U.S. Geological Survey.

This report is the first chapter of a volume to be published which will present the data collected and the results obtained from this study on the effects of strip mining. The part of this chapter dealing with the physical description contains sections which outline the topography, drainage, geology, soils, climate, hydrologic environment, and forest vegetation of the study areas and which compare the areas to point out their similarities and dissimilarities. These basic physical descriptions will not be repeated in subsequent chapters unless the physical features described are altered in some manner by the effects of mining. The part dealing with mining history and methods summarizes the prospecting and mining that were carried on in the study areas from the 1930's to 1960 . Special emphasis is placed on the mining activities carried on from 1955-1960, because these activities produced the effects that are being studied.

The data in this chapter has been gathered by many individuals, some of whom are members of the Work Group Committee. A few of these individuals have been acknowledged in the footnotes in various sections of this chapter. The others are too numerous to acknowledge here individually, but the author is extremely grateful to them for the time and effort they have given to this project.

Special recognition must be given to two individuals who have made outstanding contributions to this project. Mr. Donald E. Whelan, U.S. Forest Service, conceived this study and was instrumental in organizing the investigation. Without his initial efforts this report could not have been written. Mr. Ernest L. Hendricks, U.S. Geological Survey, has served as chairman for the Work Group Committee since the beginning of this project in 1955. His planning and guidance in many phases of this study have been responsible for the success of this project. 
The Cane Branch basin in McCreary County, Ky., where strip mining was imminent, was chosen in 1955 to be the site where data would be gathered on the effects of strip mining. Because this basin was sufficiently small and because it had undergone little previous mining, the many expected changes could be noted and documented adequately.

A basin that could be maintained physically unchanged was then selected to supply information on normal conditions in the area. This basin had to be reasonably similar to the Cane Branch basin in size, topography, geology, forest vegetation, and other physical characteristics, so that meaningful comparisons could be made with the strip-mined basin. The Helton Branch basin, about 2 miles west of the Cane Branch basin, was chosen

Later on, data were collected in the West Fork Cane Branch basin. West Fork Cane Branch is a major tributary to Cane Branch. This additional study area was decided upon when it became known that strip mining might be done there also.

Some parts of the study areas are in the Cumberland National Forest and are owned by the Federal government, and other parts are owned by private individuals. In the Helton Branch study area, 92 percent of the land is government owned and 8 percent is privately owned. In the Cane Branch study area, 44 percent is government owned and 56 percent is privately owned. Mining in the Cane Branch basin has been carried out on the privately owned lands.

Cane Branch, West Fork Cane Branch, and Helton Branch are in the headwaters of the Beaver Creek basin. Cane and West Fork Cane Branches are about 2 miles northeast of the community of Parkers Lake, Ky. (fig. 1). A part of the western boundary of the Helton Branch basin lies within the village of Greenwood, $\mathrm{Ky}$.

\section{PHYSICAL DESCRIPTION OF BEAVER CREEK BASIN}

\section{TOPOGRAPHY AND DRAINAGE}

The Beaver Creek basin is in the Cumberland Plateau physiographic section, in the part known as the Eastern Kentucky Mountains. The Cumberland Plateau is underlain by nearly horizontal strata composed of interbedded sequences of sandstone and shale. These beds have been eroded by streams to form a maturely dissected, irregular land surface with narrow, winding ridges and deep steep-sided valleys.

The Beaver Creek basin, which is roughly rectangular, is about $7 \frac{1}{2}$ miles long and $3 \frac{1}{2}$ miles wide. It has a drainage area of 25 square miles above its mouth at Lake Cumberland. The average elevation of the divides is 1,300 feet above sea level. The relief along the steep walls of the valley ranges from 200 to 400 feet. The valley floors are narrow, and the flood plains are small; the streams meander slightly in small incised channels. In many places the channel floors consist of bedrock.

Beaver Creek, the master stream of the basin, flows northward into Lake Cumberland between the elevation of 673 and 760 feet, depending on the level of the lake. The highest point in the basin is a knoll just south of Parkers Lake, Ky., which has an elevation of 1,440 feet.

Three tributaries meet near the geographical center of the Beaver Creek basin to form Beaver Creek. These tributaries are Little Hurricane Fork, Hughes Fork, and Freeman Fork (fig. 1). Helton Branch lies in the southwestern part of the basin and is a tributary of Little Hurricane Fork. Cane Branch lies in the southern part of the basin and is a tributary of Hughes Fork. West Fork Cane Branch joins Cane Branch about 2,500 feet upstream from the mouth of Cane Branch. The drainage area and range of elevation of the Helton, Cane, and West Fork Cane Branch study areas are as follows:

\begin{tabular}{|c|c|c|c|c|}
\hline \multirow{2}{*}{ Study area } & \multicolumn{2}{|c|}{$\begin{array}{l}\text { Drainage area above } \\
\text { gaging station }\end{array}$} & \multirow{2}{*}{$\begin{array}{c}\text { Channel- } \\
\text { elevation } \\
\text { at gaging } \\
\text { station } \\
\text { (feet) }\end{array}$} & \multirow{2}{*}{$\begin{array}{c}\text { Highest } \\
\text { elevation } \\
\text { in study } \\
\text { area } \\
\text { (feet) }\end{array}$} \\
\hline & $\mathrm{sq} \mathrm{mi}$ & Acres & & \\
\hline $\begin{array}{l}\text { Helton Branch } \\
\text { Cane Branch } \\
\text { West Fork Cane Branch.-. }\end{array}$ & $\begin{array}{r}0.85 \\
.67 \\
.26\end{array}$ & $\begin{array}{l}541 \\
429 \\
165\end{array}$ & $\begin{array}{r}994 \\
979 \\
1,123\end{array}$ & $\begin{array}{l}1,385-1,390 \\
1,380-1,390 \\
1,365-1,370\end{array}$ \\
\hline
\end{tabular}

One of the better methods of defining the slope of the valley walls in a basin is by an area-elevationdistribution graph which shows how the area is distributed within a basin from base to top. The areaelevation curves of figure 2 show that the land slopes of the three study areas are similar. The land surface has steep slopes above elevation 1,300 feet. The slopes become more moderate between 1,300 and 1,150 feet. The canyons begin below 1,150 feet.

The variations in the relief of the three study areas are shown in figures 3 and 4 by profiles of the ground surface. The locations of the profiles are shown by lines $A-A^{\prime}$ and $B-B^{\prime}$ on plates 1 and 2, respectively. These profiles are only representative of the selected locations through which the lines are drawn, but they convey a general impression of the topography.

Profiles of the channels and their main headwater tributaries are plotted in figure 5. The Cane Branch profile follows the main channel that rises near lat $36^{\circ} 51^{\prime} 30^{\prime \prime} \mathrm{N}$., long $84^{\circ} 26^{\prime} 00^{\prime \prime} \mathrm{W}$. (pl. 1). The profile of West Fork Cane Branch follows the main channel that rises near lat $36^{\circ} 51^{\prime} 10^{\prime \prime} \mathrm{N}$., long $84^{\circ} 26^{\prime} 50^{\prime \prime} \mathrm{W}$. (pl. 1). The Helton Branch profile follows the main 


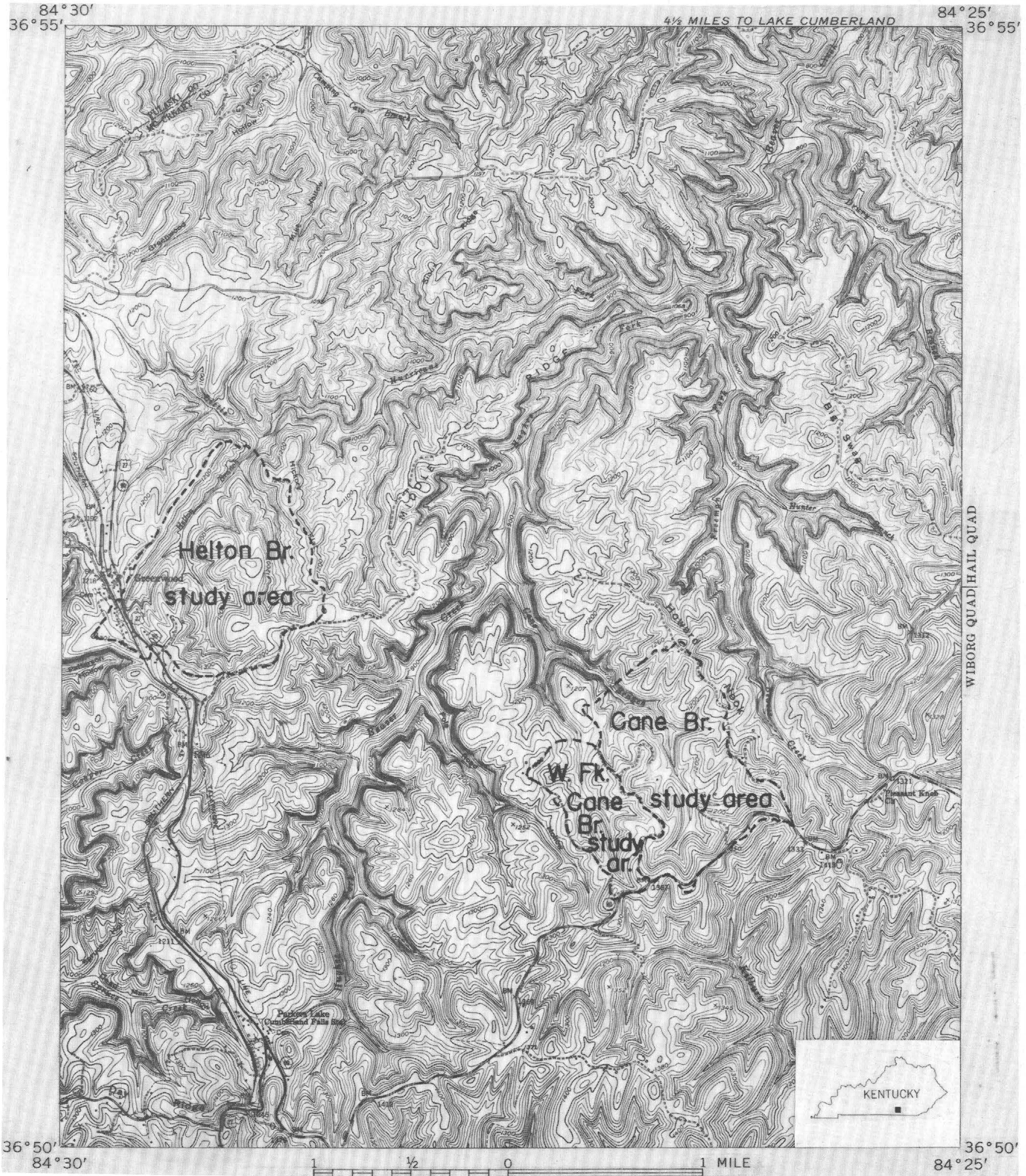

FIGURE 1,-Map of part of Beaver Creek basin showing location of Cane Branch, West Fork Cane Branch, and Helton Branch study areas, McCreary County, Ky. 


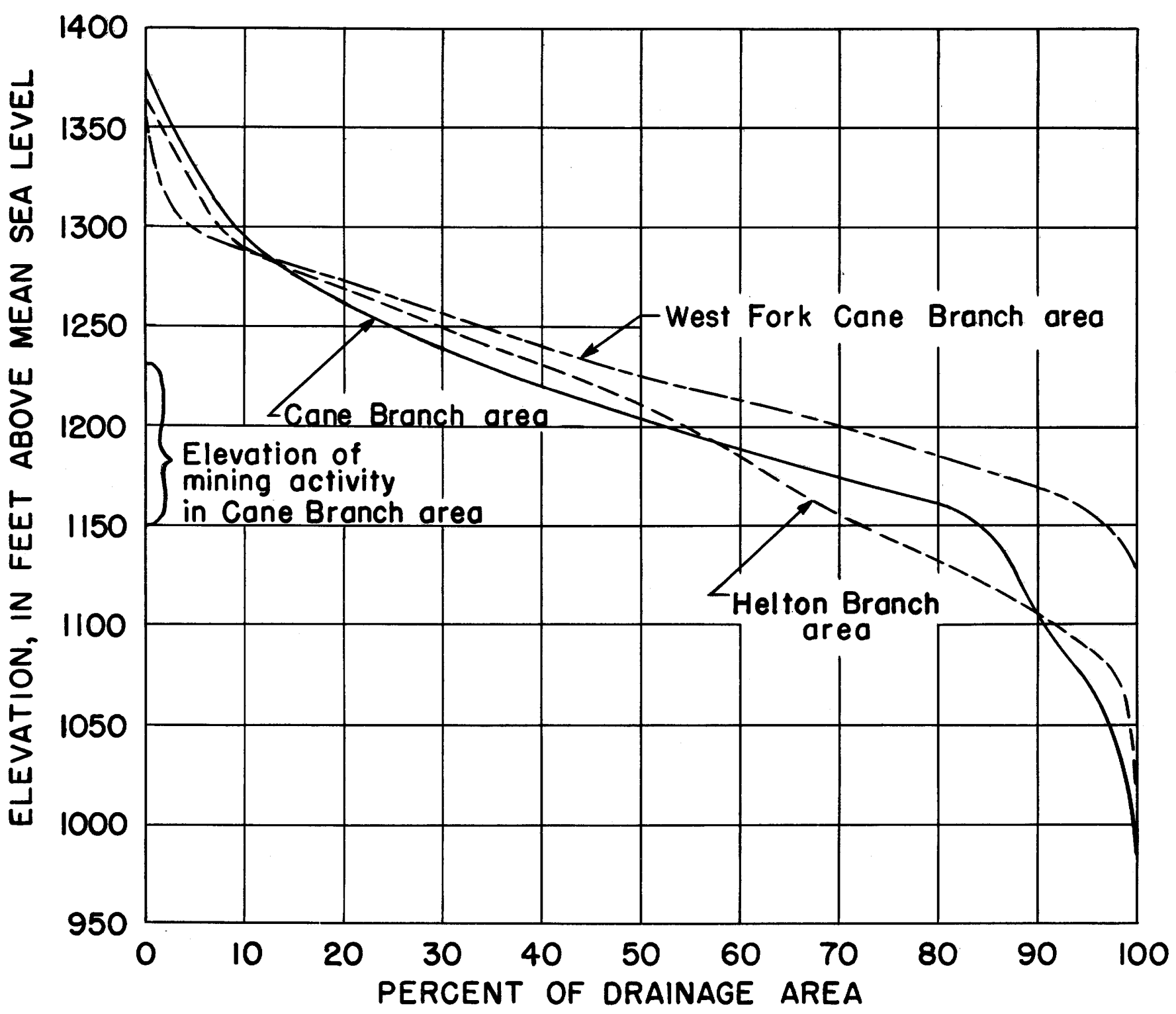

Figure 2.-Area-elevation curves of Cane Branch, West Fork Cane Branch, and Helton Branch study areas above gaging stations.

channel that rises near lat $36^{\circ} 52^{\prime} 15^{\prime \prime} \mathrm{N}$. , long $84^{\circ} 28^{\prime} 55^{\prime \prime}$ W., and trends westward for a short distance before turning north (pl. 2).

The profiles of the three streams show that the channels are steep and similar in general appearance. The pronounced break in the slope of the Cane Branch profile at 3,900 feet is due to a series of waterfalls, of which the highest is 40 feet high and the others from 1 to 3 feet high. Cane Branch has several small falls and numerous riffles below the main series of falls.

On West Fork Cane Branch in the reach of channel below the gaging station, there are two waterfalls, each approximately 15 feet high. Helton Branch has one 15-foot waterfall about 2,300 feet upstream from the gaging station; however, this waterfall is not clearly shown on the topographic map of the area and, hence, is not reflected in the profile of the channel shown in figure 5. Both streams have numerous small waterfalls and riffles.

The Helton Branch channel has a bedrock floor. Most of the sediment deposits along the channel are confined to the small pools which occur between the riffles.

The floors of the Cane and West Fork Cane Branch channels are bedrock and sediment. Although the bedrock forms the waterfalls and riffles, it makes up only a small part of the channel floors. The larger part of the channel floors consists of sediment deposited along the relatively flat parts of the channels and in the numerous pools that occur between the riffles. 


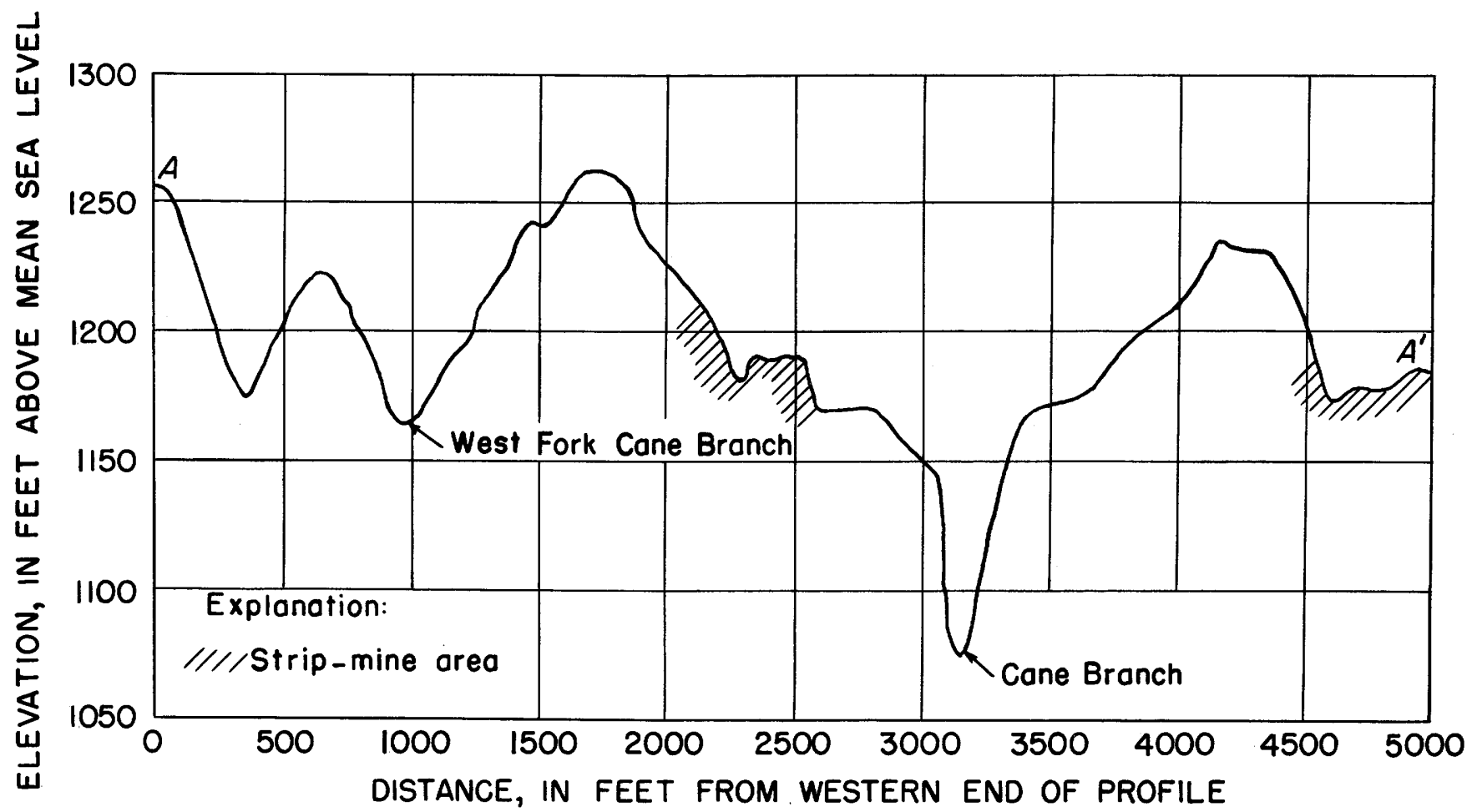

FIGURE 3.-Profile of the ground surface along section $A-A^{\prime}$, plate 1, traversing West Fork Cane Branch and Cane Branch study areas.

The valley floor is the relatively level area between the valley walls where the stream channel and the flood plains are located. In the Cane, West Fork Cane, and Helton Branch areas the valley floors range in width from a few feet to about 100 feet. The wider floors generally occur in the northern, or lower, part of each area.

The main stream channels meander back and forth along the valley floors and range in width from a few feet near the headwaters in the southern part of each area to about 15 feet in the northern part. The flood plains are generally located on the concave side of each meander. They range in height from 1 to 4 feet above the stream bed. The larger flood plains in the northern part of each area are as much as 100 feet long and 80 feet wide. They are underlain by flat-lying bedrock and are composed of detrital material that has been deposited during periods of storm runoff.

\section{GEOLOGY 1}

The bedrock in the general area drained by Cane and Helton Branches belongs to the upper part of the Lee Formation of the Pennsylvanian System. The beds are composed of quartz conglomerate and sandstone, siltstone, claystone, and coal. The beds are virtually horizontal, and some vary laterally in lithology and

1 The introductory paragraph and the section on stratigraphy were adapted from Lyons, E. J., 1957, The geology of the Cane Branch and Helton Branch watershed area, McCreary County, Kentucky: U.S. Geol. Survey open-fle rept. thickness within a few hundred feet. Figure 6 is a generalized geologic map of the study area which outlines the geologic contacts and the location of the stratigraphic sections described in the following paragraphs.

\section{GTRATIGRAPHY}

The general stratigraphic section of the Cane and Helton Branch basins may be divided into three parts as follows: (1) The strata below the main cliff-forming sandstone; (2) the main cliff-forming sandstone; and (3) the strata above the main cliff-forming sandstone, which include the principal coal bed of the area.

\section{STRATA BELOW THE MAIN CLIFF-FORMING SANDSTONE}

The strata below the main cliff-forming sandstone consist of a 35-to 45-foot sequence of sandstone, siltstone, and claystone which is exposed along the lower reaches of the Cane Branch and Helton Branch basins.

In the Cane Branch basin the basal unit of this sequence is 15 to 20 feet thick and consists of a very fine to fine-grained sandstone containing some mica and scattered ironstone concretions less than 1 inch in diameter (fig. 7, section 4). This sandstone is overlain by about 7 feet of sandy siltstone which is thin bedded to shaly in the lower part and which is without bedding in the upper part. The lower part of the siltstone contains muscovite flakes and plant fragments, and there are rootlet impressions throughout the siltstone. Above the siltstone there is 6 inches of coal boom, which, 


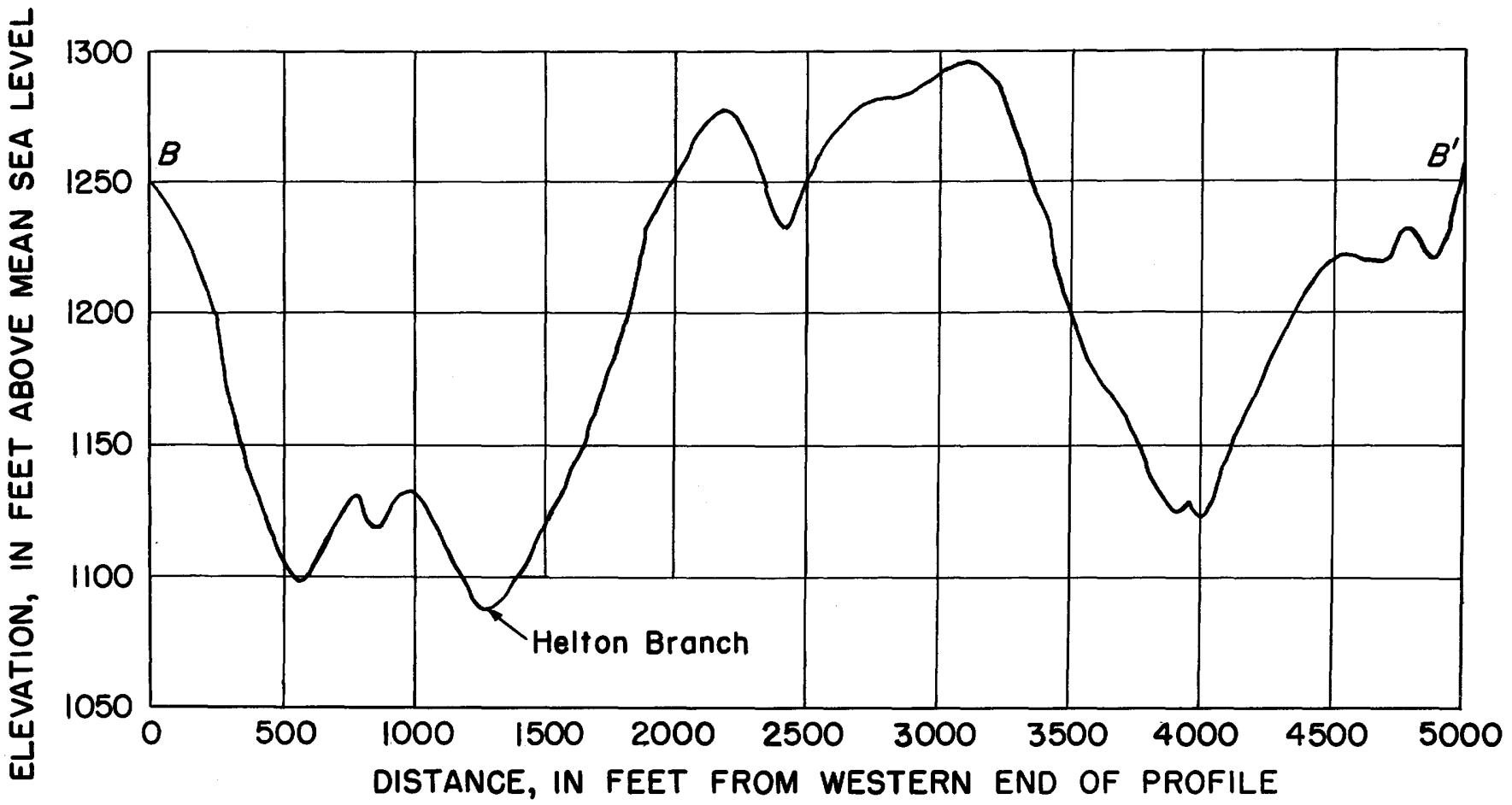

FIGURE 4.-Profile of the ground surface along section $B-B^{\prime}$, plate 2, traversing Helton Branch study area.

in turn, is overlain by about 15 feet of silty claystone containing goethite concretions as much as 3 inches in diameter. This claystone becomes sandy in the upper part.

In the Helton Branch basin the sequence below the cliff-forming sandstone consists of very fine to finegrained, crossbedded and ripple-marked sandstone containing mica flakes and plant fragments (fig. 7, section 3). The beds are less than 6 inches thick. The upper 5 to 10 feet of this sandstone grades laterally into a dark shaly siltstone or claystone which contains lenses of coaly material as much as 3 inches thick and 2 feet long.

\section{MAIN CLIFF-FORMING SANDSTONE}

The main cliff-forming sandstone consists of a sequence of sandstone and conglomerate which forms a prominent cliff along the valley walls in the lower and central reaches of the Cane and Helton Branch basins. At most places it consists of two units of coarse-grained rock separated by a thinner unit of finer grained clastic rock (fig. 7 , sections 3 and 4). In many places this entire sequence forms a cliff, but in other places only the lower or upper unit does. Cane Branch, West Fork Cane Branch, and Helton Branch form waterfalls as they flow over and through this rock sequence.

The lower unit is 80 to 90 feet thick and consists of sandstone, conglomeratic sandstone, and conglomerate. The matrix of this unit is composed of very fine to coarse sand grains. Locally, there are lenses and irregular masses of subrounded white quartz pebbles less than 2 inches in diameter. Most of the beds are at least 1 foot thick. Many beds are wedge shaped, and in places they have been scoured and the resulting channels filled with sandstone or conglomerate ${ }^{\circ}$ Crossbedding is common.

The middle unit is a zone of finer grained rock which separates the upper and lower units of coarse-grained rock throughout most of the area. In some places this unit is missing, and in other places it is as much as 5 feet thick. This unit ranges from a thin-bedded sandy siltstone with interbedded very fine grained sandstone lentils to silty claystone with interbedded siltstone layers. Coaly plant fragments are found in some exposures.

The upper unit of coarse-grained rocks ranges from 35 to 80 feet in thickness. In the Helton Branch basin this unit consists of about 35 feet of fine to mediumgrained crossbedded sandstone occurring in beds as much as 3 feet thick and containing quartz pebbles in the upper 10 feet (fig. 7, sections 2 and 3). In the Cane Branch basin the upper unit consists of a very fine to fine-grained sandstone containing mica flakes, plant fragments, and interbedded siltstone layers (fig. 7, section 4). The beds are less than 3 feet thick. Many of them are wedge shaped, and there is evidence of scouring and subsequent filling of the channels. Along the east side of the Cane Branch basin this unit is about 80 feet thick. Here it is conglomeratic, and the lower 60 feet contains white quartz pebbles. 


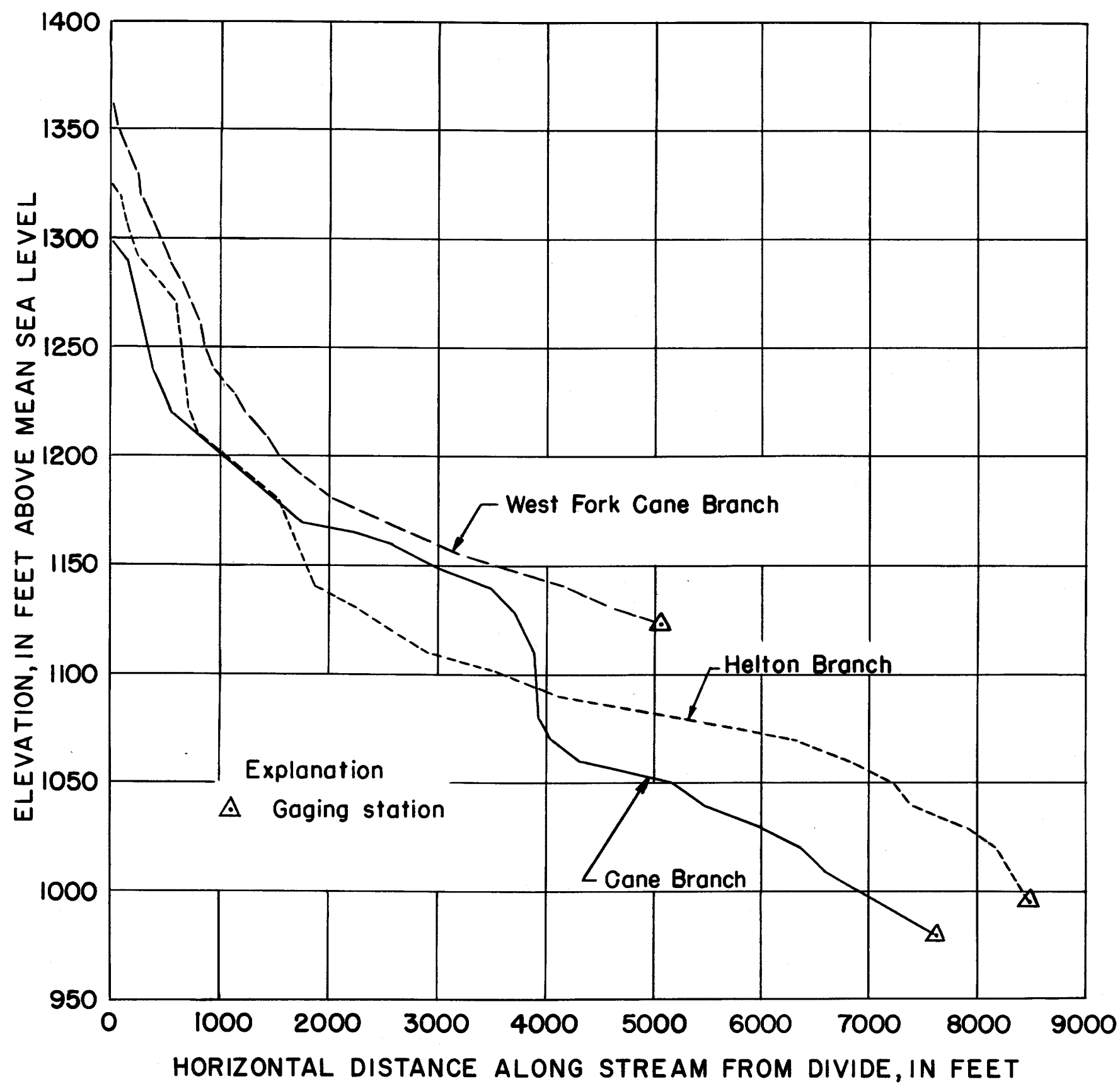

Figure 5.-Stream-channel profiles of Cane Branch, West Fork Cane Branch, and Helton Branch.

The sequence of strata which forms the main cliffforming sandstone may correlate with the Rockcastle Sandstone Member of the Lee Formation.

\section{STRATA ABOVE THE MAIN CLIFF-FORMING SANDSTONE}

In the Cane Branch and Helton Branch basins the strata above the main cliff-forming sandstone consist of a poorly exposed sequence of bedrock which is 150 to 200 feet thick. This sequence forms the upper parts of the valley walls and the divides in both basins. In many places, the meager exposures are deeply weathered.
In the Cane Branch basin and in the northern part of the Helton Branch basin this sequence consists of interbedded very fine to fine-grained sandstones, sandy siltstones, and sandy to silty claystones which contain plant fragments and coaly lenses in some places (fig. . 7, sections $3,4,5,6$, and 7 ). The coal seam that has been mined in the Cane Branch basin lies in the lower part of this sequence.

An examination of outcrops and roadcuts in and around the Helton Branch basin did not reveal the presence of this coal seam. At Parkers Lake, Ky., 


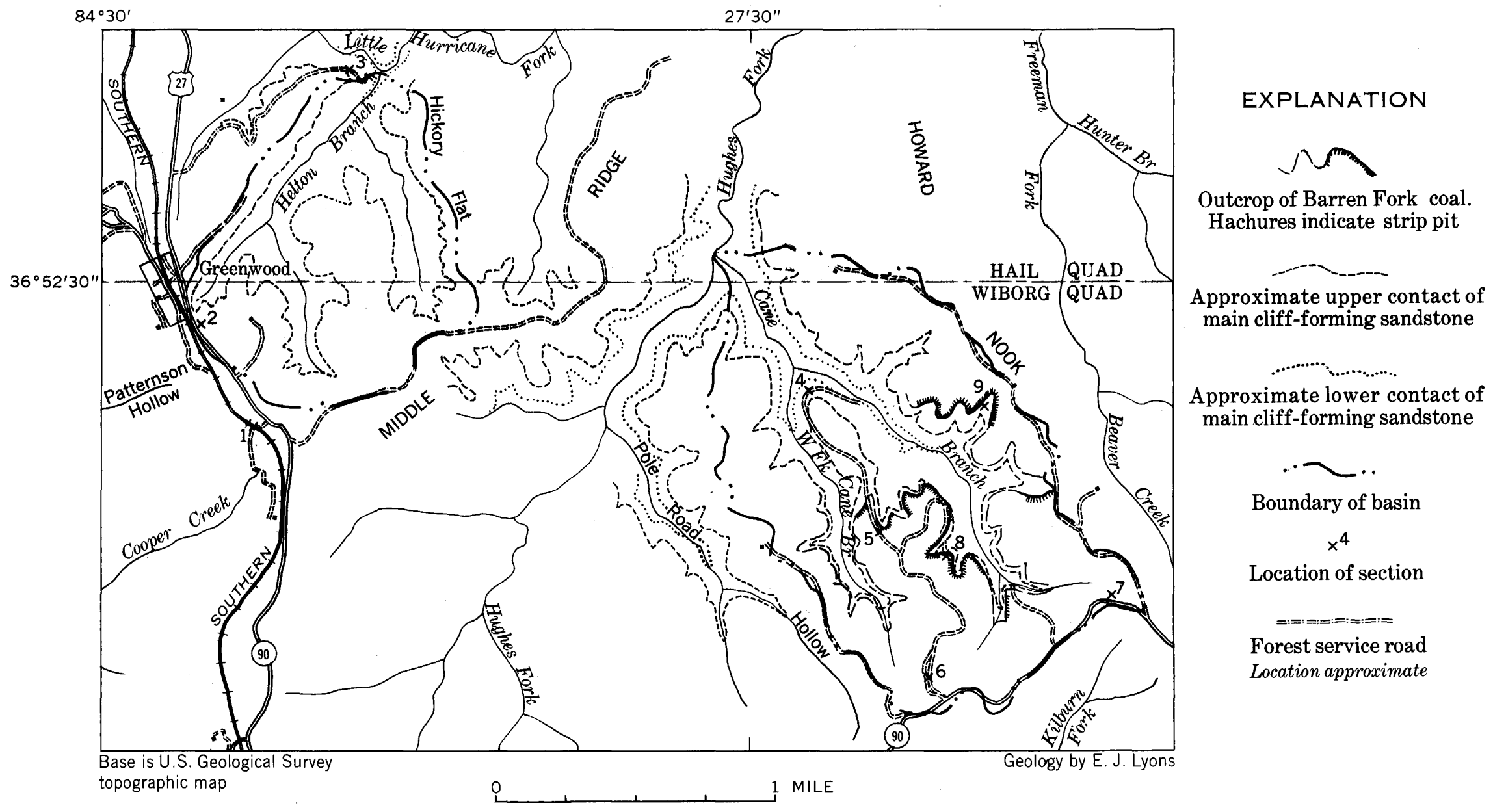

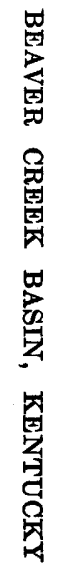

FrguRE 6. Extent of coal and cliff-forming sandstone of Pennsylvanian age exposed in or near Helton Branch and Cane Branch basins, MeCreary County, Ky. 


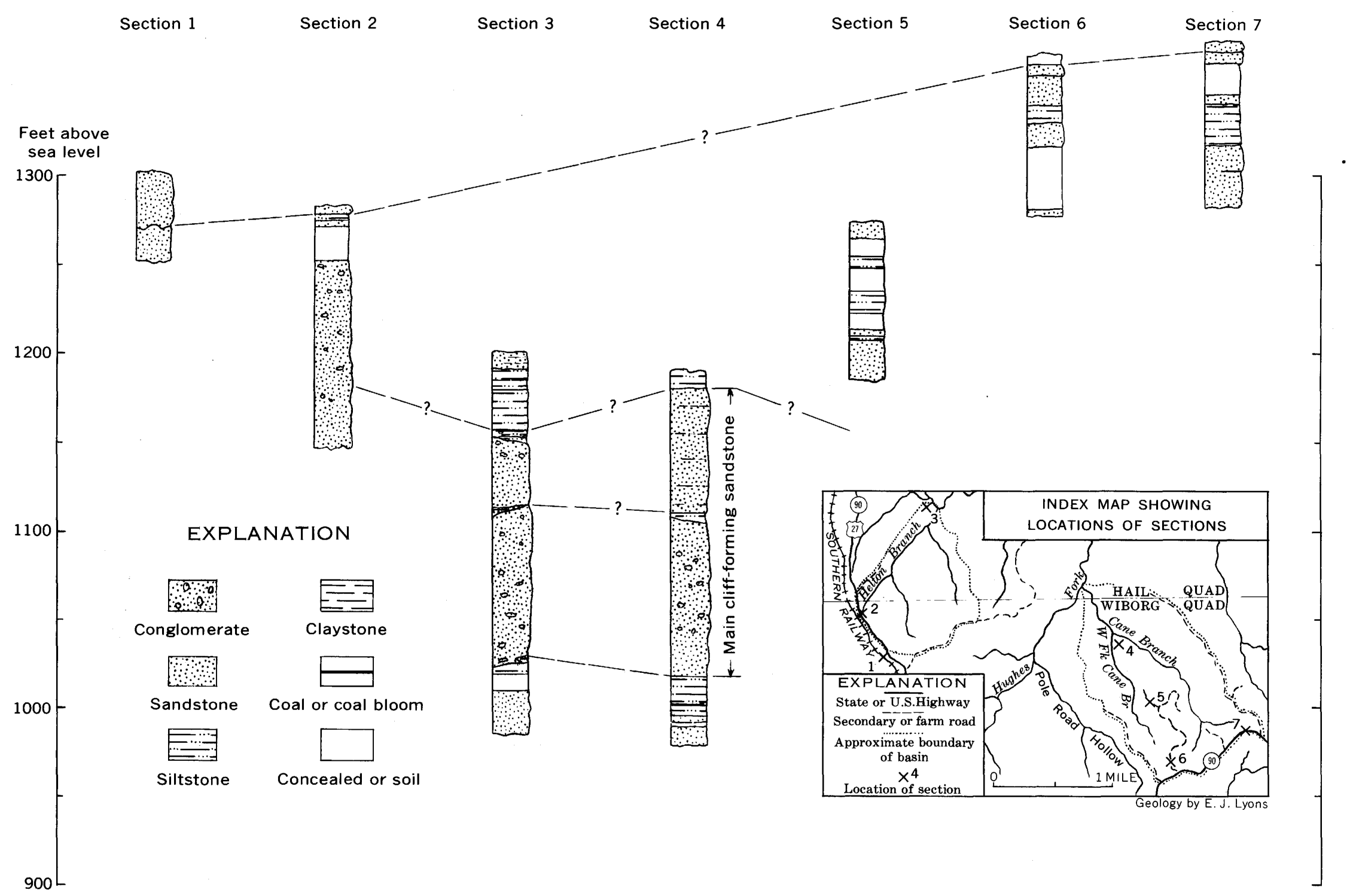


to the south of the Helton Branch basin, the coal seam is shaly and cannot be mined economically. The seam probably undergoes a facies change between Parkers Lake and the Helton Branch basin, so that in the basin its statigraphic position is represented by some of the dark claystone beds that overlie the main cliff-forming sandstone (fig. 7 , section 3 ).

In the southern part of the Helton Branch basin the sequence of strata above the main cliff-forming sandstone is predominantly sandstone. At the head of Helton Branch there is an almost continuous vertical section of sandstone and conglomerate about 100 feet thick. The lower 30 feet of this section is part of the main cliff-forming sandstone (fig. 7 , section 2). The upper 70 feet is a fine- to coarse-grained sandstone containing white quartz pebbles. Along the southeast side of the basin a fine to coarse-grained sandstone unit forms a series of ledges about 40 feet high. The base of this unit is about 40 feet above the top of the main cliff-forming sandstone. The sandstone, which occurs in beds less than 2.5 feet thick, is crossbedded and contains white quartz pebbles.

The highest rock unit in the Cane Branch and Helton Branch basins is a very fine to medium-grained friable sandstone which weathers into rounded forms having a pinkish cast. It is exposed in the southern part of the Cane Branch basin and in the southwestern part of the Helton Branch basin (fig. 7, sections 1, 2, and 7). This sandstone closely resembles the Corbin Sandstone Member which is widely exposed to the south of the Helton Branch basin along U.S. Highway 27. The Corbin Member is one of the uppermost units of the upper part of the Lee Formation above the Rockcastle Sandstone Member.

The relationships between the various stratigraphic units in the Cane and Helton Branch basins that were described in the preceding paragraphs are shown in the generalized stratigraphic sections in figure 8 .

\section{COAL SEAM IN CANE BRANCH BABIN}

The coal seam, which has been partly removed from the Cane Branch basin by strip mining, lies in the lower part of the sequence of strata above the main cliffforming sandstone. It correlates with the Barren Fork coal of nearby areas.

The coal seam is exposed in a few places in the strip pits along the northeast and southwest valley walls of the Cane Branch basin (fig. 6). On the southwest side of the basin the entire seam is 55 inches thick. In the middle of the coal seam, there is a parting of carbonaceous shale 4 to 10 inches thick. The coal above and below this parting is bright attrital, well banded, and slightly blocky. The upper 1.5 feet of this seam consists of interlaminated shale and coal. About 2 percent of the seam consists of disseminated iron sulfide, and some of the scattered blocks of coal lying nearby have yellow sulfur crystals along the bedding planes and joints. On the northeast side of the basin the coal seam is 47 inches thick. It is similar to the seam exposed on the southwest side of the basin, but there is more shale interlaminated with the coal in the upper 1.5 feet of the seam. Figure 9 shows the coal seam in the strip pit on the northeast side of the basin and many of the features which have just been described.

\section{UNCONSOLIDATED ROCKS}

The unconsolidated rocks in the study areas consist of those rock fragments that are no longer part of the bedrock, and they can be classed as 1 of 3 types of deposits as follows: The spoil banks in the areas of mining, the talus piles at the base of the steep valley walls, and the fluvial sediments along the stream channels and flood plains.

\section{SPOIL BANKS}

There are two large and several small spoil banks along the northeast and southwest valley walls of the Cane Branch basin (plate 3). These banks are composed of a heterogeneous mixture of rock and soil. The rock was originally a 40-foot sequence of strata lying directly above the Barren Fork coal seam in the valley walls. These strata were removed from the walls and were piled haphazardly on undisturbed ground and in the pit left by the strip-mining operations.

The following stratigraphic sections were measured along the highwalls in the two principal areas of mining in the Cane Branch basin. Figure 10 shows the highwall on the southwest side of the basin, where section 8 was measured and described. Figure 11 shows the highwall on the northeast side of the basin, where section 9 was measured and described. The rock units that are described are representative of the strata included in the spoil banks. 
Cane Branch

Basin

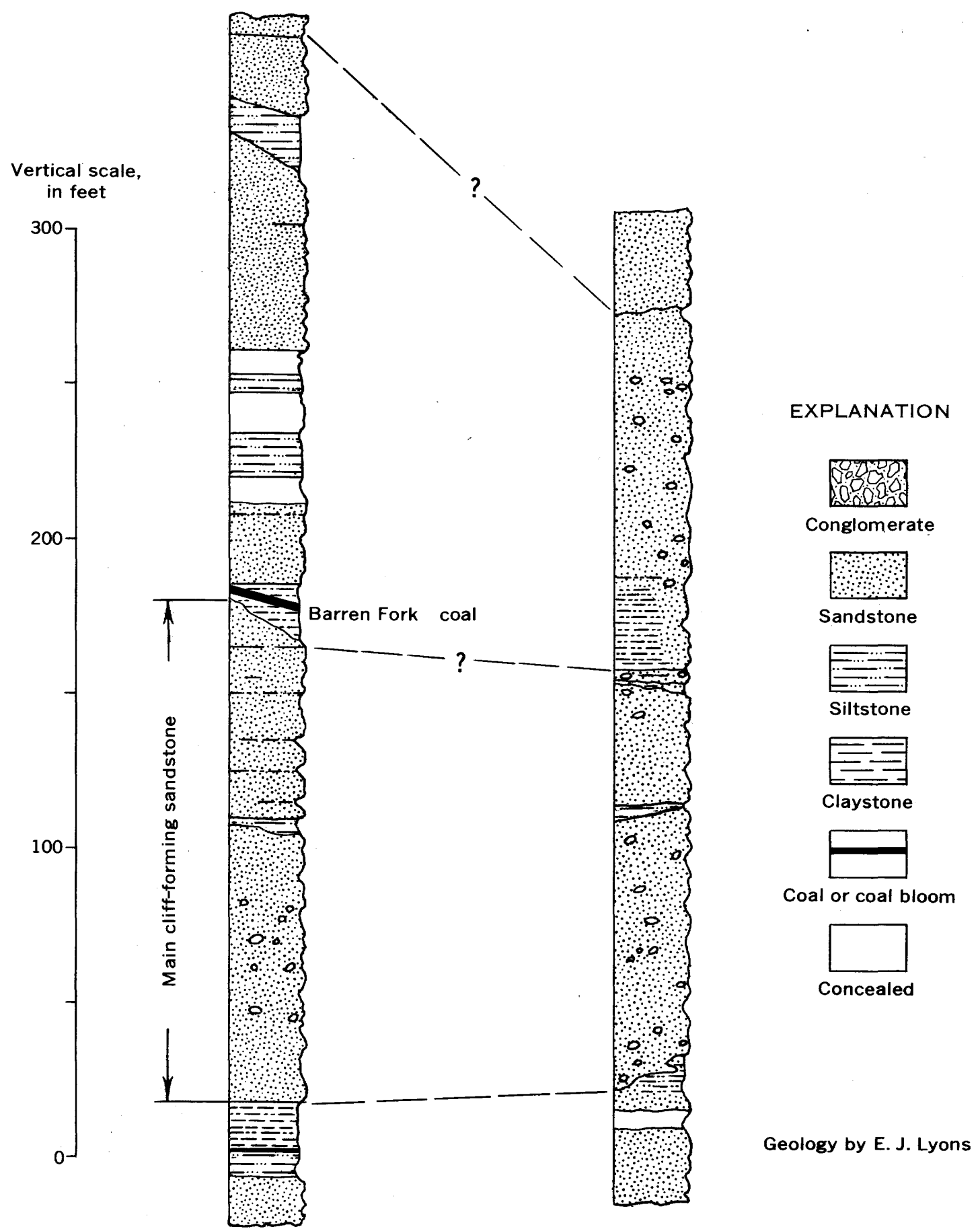

Froure 8.-Generalized sections of rocks of Pennsylvanian age present in Helton Branch and Cane Branch basins, McCreary County, Ky. 


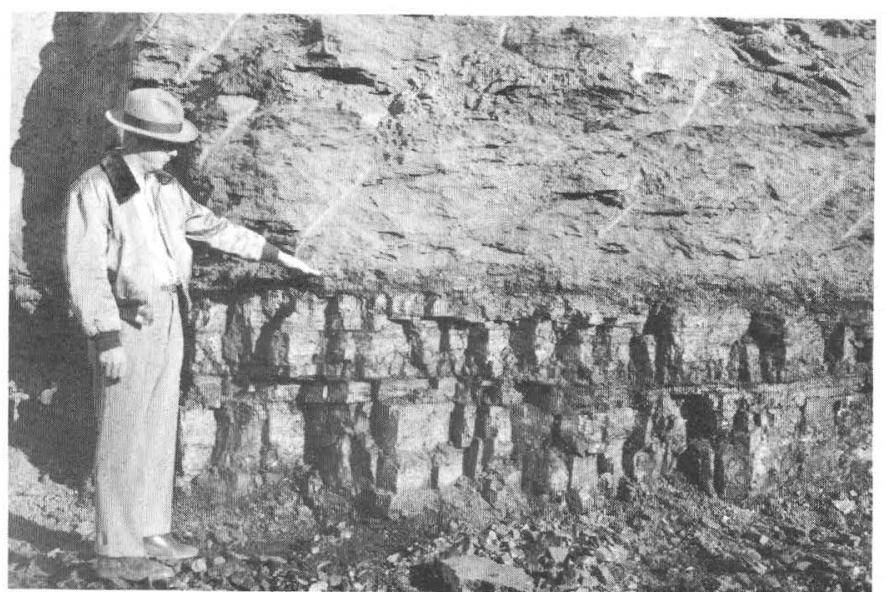

Figure 9.-The coal seam in the Cane Branch basin. The man's hand denotes the top of the seam.

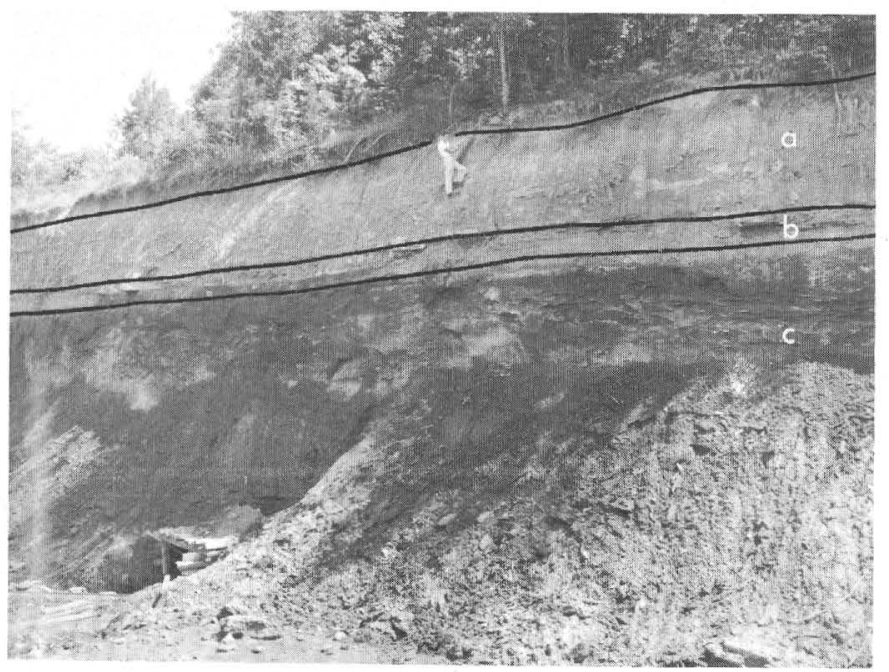

Figure 10.-The highwall on the southwest side of the Cane Branch basin showing the rock units described in section 8 . a, claystones of units $1-6 ; b$, sandstone marker bed of unit 7; c, siltstones of units 8-15. Coal seam is visible only in the drift mine.

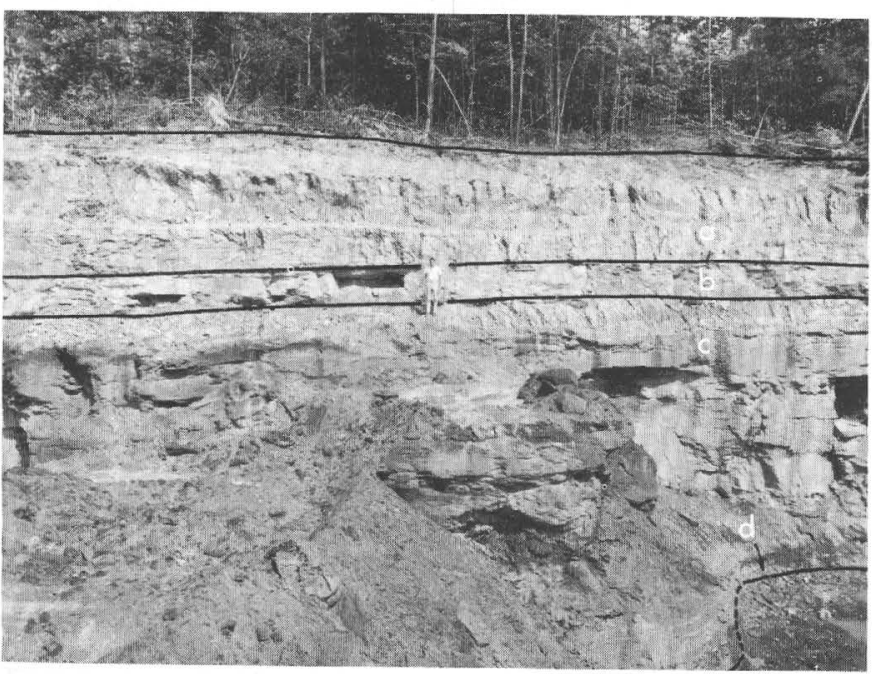

Figure 11.-The highwall on the northeast side of the Cane Branch basin showing the rock units described in section 9 . a, claystones of units $1-3 ; b$, sandstone marker bed of units 4-5; c, siltstones of units 6-11; d, top of coal seam.

8. Section in the central part of the highwall at the large spoil bank on the southwest side of the Cane Branch basin

[Fig. 6, section 8]

Unit and description

Thickness (feet)

1. Soil zone at top of highwall, well-weathered claystone with scattered mica flakes.....................

2. Claystone, weathered, light-brown; bedding obliterated; contains scattered mica flakes.

3. Claystone, weathered, light-brown to medium-brown to pale-lavender; indistinct thin beds; contains scattered mica flakes and a few lenses of very fine sand.-

4. Claystone, weathered, light-brown to medium-brown to pale-lavender; thin (one-eighth in.) beds; contains scattered mica flakes. Some interbedded lenses of very fine sand, $1 / 8$ to $1 / 2$ in. thick . . . . . . .

5. Claystone, weathered, light-brown to medium-brown to pale-lavender; indistinct bedding; contains scattered sand grains and mica flakes.

6. Claystone, weathered, light-brown to medium-brown to lavender; indistinct bedding; contains a few sand grains and scattered mica flakes...............

7. Sandstone, white to medium-brown, strongly iron stained; grains are $1 / 16$ to $1 / 2 \mathrm{~mm}$ in diameter and consist mostly of quartz with scattered mica grains. Lower part of unit is a massive bed, $2 \mathrm{ft}$ thick; upper part consists of thin beds, 1 to 3 in. thick, that are somewhat weathered. This unit forms a marker bed that can be traced around the highwall of the west strip mine.

8. Sandstone, siltstone, and claystone interbedded; all shades of brown; scattered mica flakes............

9. Claystone, light-brown to yellow; contains many thin interbedded sandstones and scattered mica flakes..

10. Siltstone and fine-grained sandstone, dark-gray to black; thin lentils; scattered mica flakes; some disseminated pyrite may be present............

11. Siltstone and fine-grained sandstone, dark-gray to black; thin lenses and beds; scattered mica flakes. A zone of pyrite (marcasite?) nodules $1.0 \mathrm{ft}$ below top of unit. Nodules are as much as 1 in. in diameter and 5 in. long. Unit contains water-soluble sulfur compounds . . . . . .

12. Claystone, weathered, brown and gray, laminated; a few sand grains and mica flakes are present; contains water-soluble sulfur compounds.............

13. Siltstone and claystone, weathered, medium-gray to yellow-brown, laminated, scattered mica flakes and water-soluble sulfur compounds

14. Siltstone and claystone, weathered, medium- to darkgray, iron-stained well-laminated; a few interbedded zones of very fine sand; contains mica flakes and water-soluble sulfur compounds

15. Claystones and poor coal, well-weathered, medium- to dark-gray; contains mica flakes and water-soluble sulfur compounds

16. Barren Fork coal seam (remainder of coal seam is covered by water) Total 
9. Section in the southern part of the highwall at the large spoil bank on the northeast side of the Cane Branch basin

[Fig. 6, section 9]

Unit and description

Thickness
(feet)

1. Soil zone at top of highwall, well-weathered, and clay, sand, and small pebbles; some roots . . . . . . . . . . . .

2. Claystone, well weathered, reddish-brown; contains scattered sand grains and mica flakes; indistinct bedding.

3. Claystone, weathered, yellow to brown; distinct thin beds; contains scattered mica flakes and a few lenses of siltstone and sandstone.

4. Sandstone, white to medium-brown, strongly iron stained; grains are $1 / 16$ to $1 / 2 \mathrm{~mm}$ in diameter and consist of quartz grains and scattered mica flakes. This unit is a massive sandstone bed and forms a marker bed that can be traced around the highwall of the east strip mine.

5. Sandstone, weathered, yellow-brown; grains are $1 / 10$ to $1 / 2 \mathrm{~mm}$ in diameter and consist of almost pure quartz and some mica flakes. Unit is probably part of sandstone marker bed that has been well weathered.

6. Claystone, siltstone, and very fine grained sandstone, dark-gray to black, well-laminated; many mica flakes; small yellow grains of sulfur. Sample emits a distinct sulfurous odor and contains water-soluble sulfur compounds . . . . . . . . . . . . . . . . . . .

7. Siltstone and fine-grained sandstone with clay partings, laminated, dark-gray to black; sandstone predominates; contain scattered mica flakes and water-soluble sulfur compounds . ..............

8. Siltstone and fine-grained sandstone, dark-gray to black, well-laminated. Samples emit slight sulfurous odor. Zone of pyrite (marcasite?) nodules 1.3 feet below top of unit. Nodules as much as 3 inches long and 1 inch in diameter. Unit contains many mica flakes and water-soluble sulfur com-

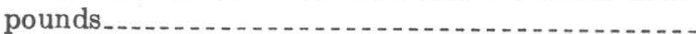

9. Siltstone and fine-grained sandstone, dark-gray to black, well-laminated. Samples emit slight sulfurous odor. Sand grains are as large as one-quarter of a millimeter. Contains mica flakes and watersoluble sulfur compounds......................

10. Siltstone and fine-grained sand, intermixed, slightly weathered, dark-gray to black, partly iron stained, well-laminated; many mica flakes and water-soluble sulfur compounds.

11. Sandstone and siltstone intermixed, well laminated, light-gray to black, sand grains are as large as onequarter of a millimeter; mostly quartz grains; contains scattered mica flakes and water-soluble sulfur compounds

12. Barren Fork coal seam

Total

In general, sections 8 and 9 are very similar, and therefore the composition of the two large spoil banks on each side of the Cane Branch basin is also similar. In both sections the Barren Fork coal seam is overlain by a 23- to 25 -foot sequence of dark-gray to black claystone, siltstone, and sandstone. This sequence contains distinct amounts of sulfur, as shown by the presence of iron sulfide nodules and the sulfide odor emitted by many of the samples collected. In addition to this physical evidence, the results of partial chemical analyses indicate the presence of water soluble sulfur compounds. Also, both sections contain a prominent sandstone bed, about 4 feet thick, overlying the sulfurbearing sequence. The upper part of each section consists of a light-colored sequence of well-weathered claystones about 15 feet thick.

\section{TALUS PILES}

Talus piles are an accumulation of angular rock fragments at the foot of a steep slope. In the study areas, they are composed of sand- to boulder-size fragments that have wasted from the main cliff-forming sandstone. They are generally found on the flood plains at the base of the steep valley walls in the Cane Branch, West Fork Cane Branch, and Helton Branch basins.

The larger piles consist mainly of boulders and are sometimes built to heights of 20 feet or more above the valley floor. One outstanding pile of fragments has accumulated about 100 feet downstream from the highest waterfall on Cane Branch. This pile, about 200 feet long parallel to the canyon wall and about 25 feet high, consists mainly of boulders which weigh several tons each.

The smaller piles consist mainly of sand- to cobblesize fragments. Those piles which have accumulated adjacent to the stream channels are subject to erosion during periods of excessive runoff.

(1)
claystones and siltstones exposed in the spoil bank are the main source of the fine-grained fluvial deposits.

The lower flood plains in the Cane Branch canyon are covered with thin deposits of clay- to cobble-size particles. The higher flood plains have not been inundated since the strip mining began and are composed of sand and gravel. Before mining, the lower 
flood plains undoubtedly were covered with deposits similar to those found on the higher flood plains.

The fluvial deposits along the stream channel and flood plains of Helton Branch are representative of the natural conditions along most of the streams in the Beaver Creek basin. Most of the floor of the Helton Branch channel consists of bedrock, but there are scattered deposits of sand- to boulder-size fragments, with sand and gravel predominating. The upper few inches of the flood plains are composed of sand mixed with a small amount of gravel. Silt and clay are not abundant in these fluvial deposits because the percentage of exposed source rocks for these sizes is small.

The channel deposits of West Fork Cane Branch above the gaging station consist mostly of silt- to cobble-size particles and a few boudders. The bedrock floor of the channel is only visible in the few places where it forms riffles. The flood plains near the gaging station are covered with silt and sand. In the steepwalled canyon below the gaging station the channel floor consists mostly of bedrock, and fluvial deposits are not abundant. There are many large boulders in the channel. Flood plains are practically nonexistent.

\section{soILs 2}

\section{GENERAL DESCRIPTION}

Several great soil groups occur within the Cane, West Fork Cane, and Helton Branch study areas. The RedYellow Podzolic group is represented by the Enders, Jefferson, Tilsit, Hartsells, and Wellston soil series; the Planosol group (with fragipans) is represented by the Johnsburg series, and the Alluvial group by the Stendal series. The Muskingum series is a lithosolic soil, considered a Lithosol in the past but now believed marginal to the Sol Brun Acide group.

The geologic formations that serve as parent materials and the topographic features both have had a strong influence on soil development within these study areas. The cliff-forming-sandstones have dominated the shaping of the land features. Below the cliffs talus conceals all soil-forming materials, whereas immediately above the cliffs slopes are very steep to steep, gradually becoming more gentle near the ridge tops.

The geologic formations providing the parent materials have determined the texture and have affected other properties of the soils. Immediately above the cliffs, sandstones and siltstones have given rise to the coarser textured Hartsells soils. At higher elevations, siltstones predominate and the Wellston soils have formed. The Johnsburg and Tilsit soils have developed from similar parent materials, but local topography has had a strong influence on their character.

2 From A. S. Johnson, Somerset, Ky., and John W. Roehl, Spartanburg, N.C. (written communications), both of U.S. Soil Conservation Service.
Shales have dominated the parent material at two levels. Those at the lower level have provided the material for one small area of Enders soils found at the head of Cane Branch. Similar shales at the higher level have given rise to the Enders soils on the divides of both the Helton Branch and Cane Branch study areas.

The lithosolic Muskingum soils occur on the steep and very steep slopes. On sites where sandstones predominate, Muskingum fine sandy loam has formed.

The hydrologic classification of soils ${ }^{3}$ provides a means of comparing the runoff potential of the three gaged study areas on the basis of soils alone. In this classification the soil series throughout the country are arranged into four groups according to their ability to infiltrate water from a heavy storm after they have been thoroughly wetted. No consideration is given the slope gradient or length of slope as variables; and, for the purpose of the classification, the soils are considered as being without the benefit of vegetative cover.

Soils in hydrologic group $A$ are typified by coarse deep sands having high rates of infiltration and internal water movement. Soils in group D are mostly clays having high swelling characteristics when wet and having low rates of infiltration and internal water movement. Shallow soils that have nearly impermeable subhorizons also belong in group $\mathrm{D}$. The soils in groups $\mathrm{B}$ and $\mathrm{C}$ have characteristics intermediate between those defined for groups $\mathrm{A}$ and $\mathrm{D}$.

The distribution, in percent, of the hydrologic groups of soils in each study area is as follows:

\begin{tabular}{|c|c|c|}
\hline \multirow{2}{*}{ Study ares } & \multicolumn{2}{|c|}{ Hydrologic soll group } \\
\hline & B & c \\
\hline Cane Branch. ........ & 31 & 69 \\
\hline West Fork Cane Branch. & 41 & 59 \\
\hline Helton Branch & 34 & 66 \\
\hline
\end{tabular}

The foregoing tabulation indicates the similarity of the Helton Branch and Cane Branch study areas in terms of the potential runoff insofar as the soils are concerned. The West Fork Cane Branch area, although differing somewhat from the other areas in the distribution of the hydrologic groups, does not vary greatly.

The approximate acreages of the map units of the soil series occurring in each of the three areas are given in table 1. The kinds and distribution of the soils in the areas are shown on the soils maps, plates 4 and 5 . Descriptions of the soils follow.

${ }^{3}$ U.S. Soil Conservation Service, 1957, Engineering handbook: U.S. Dept. Agriculture, sec. $\quad 4$, supp. A. 
Table 1.-Distribution of soils in Cane Branch, West Fork Cane Branch, and Helton Branch study areas

[Figures are given in acres. Determined from soil surveys made by the U.S. Soil Conservation Service]
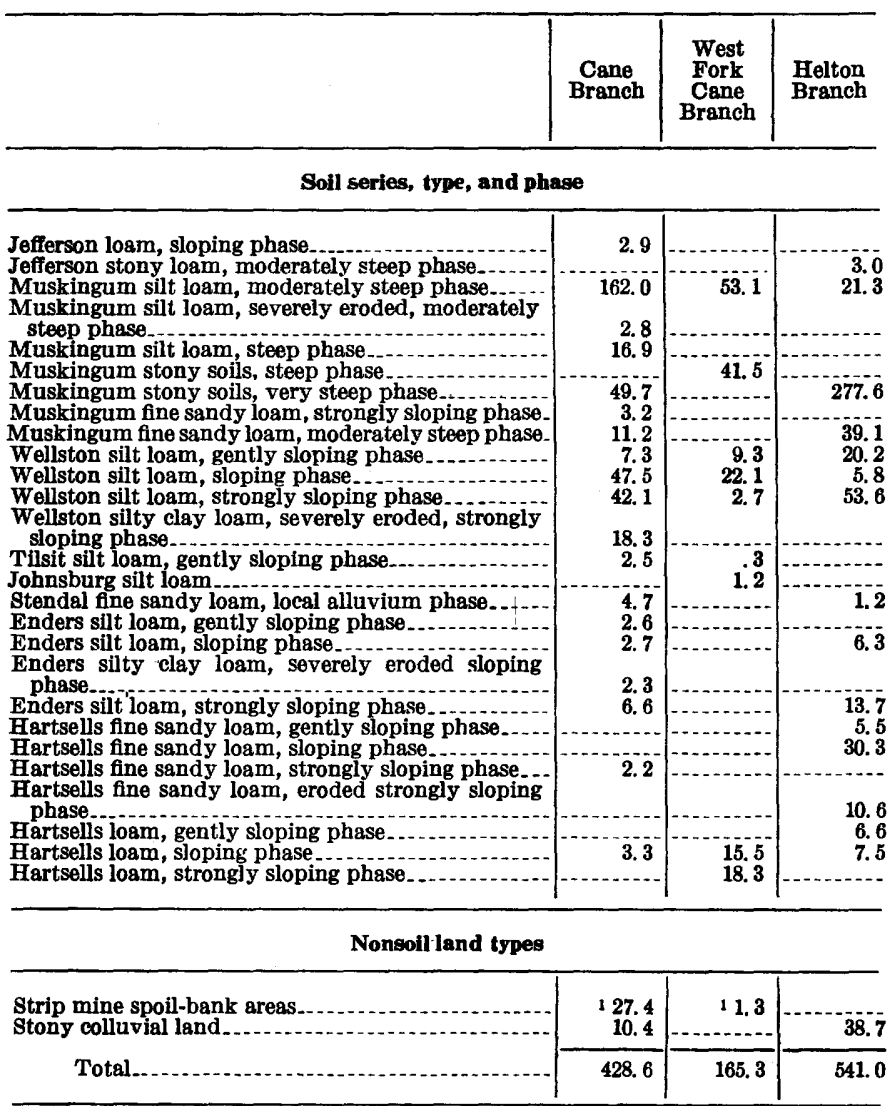

${ }^{1}$ As of January 1, 1959.

ENDERS SERIES

The Enders series consists of well-drained RedYellow Podzolic soils formed in residuum from acid shales and thin-bedded sandstones. The Enders soils have fine-textured horizons.

Four units were mapped within the study areas and are described as follows:

Unit

Description

803 B1 Enders silt loam, gently sloping phase (2-6 percent). This soil occupies gentle slopes, has good external and internal drainage, and is medium to strongly acid throughout the profile.

$\begin{array}{cc}\text { Hort- } & \text { Depth } \\ \text { (inches) }\end{array}$

$A_{p} \quad 0-6$ Brown $(10 Y R \text { 5/3 })^{1}$ friable silt loam with weak medium granular structure.

$\mathrm{B}_{2} \quad 6-15$ Reddish-brown $(5 Y R \quad 5 / 4)$ friable sandy clay with moderate medium subangular blocky structure.

$B_{3} \quad 15-30$ Variegated yellowish-brown (10YR 5/4) and gray (5YR 5/1) firm sticky plastic silty clay with moderate medium angular blocky structure.

\begin{abstract}
Unit Hori- $\begin{gathered}\text { Depth } \\ \text { (inches) }\end{gathered} \quad$ Description
$803 \mathrm{~B} 1-\mathrm{C} \quad 30-40$ Variegated yellow $(2.5 Y \quad 7 / 6)$, red Con. $\quad(2.5 Y R \quad 4 / 6)$, and gray $(5 Y 5 / 1)$ firm sticky plastic silty clay with shale fragments; moderate angular blocky structure.

D 40+ Bedrock of shale, siltstone, and sandstone that is partly decomposed and often fractured.
\end{abstract}

$803 \mathrm{C1}$ Enders silt loam, sloping phase (6-12 percent).

803 C3 Enders silty clay loam, severely eroded sloping phase (6-12 percent); it differs from the gently sloping phase chiefly by having a silty-clay-loam texture at the surface due to exposure of underlying layers to weathering during erosion. The surface soil is reddish brown.

803 D1 Enders silt loam, strongly sloping phase (12-20 percent); it differs from the gently sloping phase by having a solum that is a little thinner.

\section{JEFFERSON SERIES}

The Jefferson series consists of well-drained RedYellow Podzolic soils formed on foot slopes in old local alluvium washed from upland soils of acid sandstone and shale origin. The texture throughout the profile is strongly influenced by the sandstone component; the subsoil texture is that of clay loam or fine sandy clay loam.

Two units were mapped within the study areas and are described as follows:

Unit Description

$42 \mathrm{C1}$ Jefferson loam, sloping phase (6-12 percent). This soil occupies sloping land, has good external and internal drainage, and is strongly to very strongly acid throughout its profile.

Hori- Depth
zon

A $\quad$ 0-3 Very dark grayish brown (10YR 3/2) to dark-grayish-brown (10YR 4/2) very friable loam with weak fine granular structure.

$A_{2} \quad 3-10$ Pale-brown (10YR 6/3), brown (10YR $5 / 3)$, or light-yellowish-brown $(10 Y R 6 / 4)$ very friable loam with weak fine granular structure.

$B_{1} \quad 10-16$ Yellowish-brown $(10 Y R 5 / 6)$ to brownish-yellow $(10 Y R$ 6/6) friable to firm fine sandy clay loam with moderate medium subangular blocky structure.

$\mathrm{B}_{2} \quad 16-28$ Strong-brown $(7.5 Y R \quad 5 / 6)$ friable to firm fine sandy clay loam with moderate medium to coarse subangular blocky structure.

$\mathrm{B}_{3} \quad$ 28-34 Yellowish-brown $(10 Y R \quad 5 / 6)$ firm fine sandy clay loam with coarse angular and subangular blocky structure.

C $34+$ Variegated yellowish-brown (10YR $5 / 6)$, yellowish-red $(5 Y R 5 / 6)$, and gray $(5 Y 5 / 1)$ fine sandy loam and clay loam with weak angular blocky structure; mixture is friable.

1 Munsell color notation used when soll is molst. 
Unit

Description
Small gravel composed of sandstone is present throughout the profile, increasing in size and abundance with depth.

43 E1 Jefferson stony loam, moderately steep phase (20-30 percent); it differs from the loam (sloping phase) chiefly in containing a varying amount of stones throughout the profile; a few boulders occur on the surface or in the soil profile.

\section{THLSIT SERIES}

The Tilsit series consists of moderately well-drained Red-Yellow Podzolic soils with fragipans which developed in residuum from interbedded acid sandstones, siltstones, and shales. The $B$ horizons above the fragipans are silty clay loams.

One unit was mapped in the study areas and is described as follows:

Unit

86 B1

\section{Description}

Tilsit silt loam, gently sloping phase (2-6 percent). This soil occupies gentle slopes. It is moderately well drained, with medium runoff and medium internal drainage. It is strongly acid to very strongly acid throughout the profile.

$\begin{array}{cc}\text { Hori- } & \begin{array}{c}\text { Depth } \\ \text { (inches) }\end{array} \\ \mathrm{A}_{1} & 0-6\end{array}$

$A_{1} \quad 0-6$ Grayish-brown $(10 Y R \quad 5 / 2)$ friable silt loam with weak fine granular structure.

A $\quad$ 6-10 Light-yellowish-brown $(2.5 Y$ 6/4) friable silt loam with weak fine granular structure.

$B_{21} \quad 10-13$ Light-olive-brown $(2.5 Y \quad 5 / 4)$ silty clay loam with moderate medium subangular blocky structure.

$B_{22} \quad 13-26$ Yellowish-brown $(10 Y R \quad 5 / 6)$ silty clay loam with moderate medium subangular and angular blocky structure.

$\mathrm{B}_{\mathrm{zm}} 26+$ Mottled strong-brown (7.5YR 5/6), yellowish-brown $(10 Y R 5 / 6)$, and pale-yellow $(5 Y 7 / 4)$ firm, compact silty clay loam with moderate medium angular blocky structure.

\section{HARTSELLS SERIES}

The Hartsells series consists of well-drained RedYellow Podzolic soils developed in residuum from levelbedded medium-grained sandstones containing thin shale strata. They have significant amounts of sand throughout the profile. The texture of the B horizons is commonly that of sandy clay loam. Seven units were mapped within the study areas and are described as follows:

Unit Description

805 B1 Hartsells fine sandy loam, gently sloping phase (2-6 percent). This soil occupies gentle slopes, is well drained, and is strongly acid throughout the profile.

$$
\text { zon (inches) }
$$

$\mathrm{A}_{1} \quad 0-2 \quad$ Grayish-brown $(2.5 Y 5 / 2)$ very friable fine sandy loam with weak granular structure.

\begin{tabular}{|c|c|c|c|}
\hline Unit & $\begin{array}{l}\text { Hori- } \\
\text { zon }\end{array}$ & $\begin{array}{c}\text { Depth } \\
\text { (inches) }\end{array}$ & Deseription \\
\hline $\begin{array}{l}5 \mathrm{~B} 1- \\
\text { n. }\end{array}$ & $\mathbf{A}_{2}$ & $2-8$ & $\begin{array}{l}\text { Light-olive-brown }(2.5 Y \quad 5 / 4) \text { very } \\
\text { friable fine sandy loam with weak } \\
\text { granular structure. }\end{array}$ \\
\hline & $\mathbf{B}_{1}$ & $8-13$ & $\begin{array}{l}\text { Light-yellowish-brown }(2.5 Y \text { 6/4) fri- } \\
\text { able fine sandy loam with weak } \\
\text { subangular blocky structure. }\end{array}$ \\
\hline & $\mathbf{B}_{2}$ & $12-25$ & $\begin{array}{l}\text { Yellowish-brown (10YR 5/6) friable } \\
\text { sandy clay loam with weak to } \\
\text { moderate subangular blocky struc- } \\
\text { ture. }\end{array}$ \\
\hline & D & $25+$ & $\begin{array}{l}\text { Bedrock of sandstone that is partially } \\
\text { decomposed for } 3-8 \text { in. The depth } \\
\text { of bedrock varies and in places may } \\
\text { exceed } 30 \text { in. }\end{array}$ \\
\hline
\end{tabular}

805 C1 Hartsells fine sandy loam, sloping phase (6-12 percent).

805 D1 Hartsells fine sandy loam, strongly sloping phase (12-20 percent); differs from the gently sloping phase by having a little thinner solum.

$805 \mathrm{D}_{2}$ Hartsells fine sandy loam, eroded strongly sloping phase (12-20 percent); it differs from the gently sloping phase in having a lighter color at the surface due to exposure of underlying layers to weathering during erosion and a solum that is a little thinner.

$806 \mathrm{~B} 1$ Hartsells loam, gently sloping phase (2-6 percent). This soil occupies gentle slopes, is well drained, and is strongly acid throughout the profile.

\begin{tabular}{|c|c|c|}
\hline$\underset{20 n}{\text { Hori- }}$ & $\begin{array}{c}\text { Depth } \\
\text { (inches) }\end{array}$ & \\
\hline $\mathbf{A}_{1}$ & $0-2$ & $\begin{array}{l}\text { Dark-grayish-brown }(10 Y R 4 / 2) \text { very } \\
\text { friable loam with weak fine granular } \\
\text { structure. }\end{array}$ \\
\hline $\mathbf{A}_{2}$ & $2-10$ & $\begin{array}{c}\text { Brown }(10 Y R 5 / 3) \text { very friable loam } \\
\text { with weak fine granular structure. }\end{array}$ \\
\hline $\mathrm{B}_{1}$ & $10-15$ & $\begin{array}{l}\text { Yellowish-brown (10YR 5/4) friable } \\
\text { loam with weak fine subangular } \\
\text { blocky structure. }\end{array}$ \\
\hline $\mathbf{B}_{2}$ & $15-28$ & $\begin{array}{l}\text { Dark-yellowish-brown (10YR 4/4) } \\
\text { friable sandy clay loam with mod- } \\
\text { erate fine and medium subangular } \\
\text { blocky structure. }\end{array}$ \\
\hline C & $28-30$ & $\begin{array}{l}\text { Strong-brown partially weathered } \\
\text { sandstone. }\end{array}$ \\
\hline D & $30+$ & $\begin{array}{l}\text { Bedrock of sandstone. The depth to } \\
\text { bedrock is } 25 \text { to } 33 \text { in. }\end{array}$ \\
\hline
\end{tabular}

$806 \mathrm{C} 1$ Hartsells loam, sloping phase (6-12 percent).
$806 \mathrm{D} 1$ Hartsells loam, strongly sloping phase (12-20 percent).

\section{WELLSTON SERIES}

The Wellston series consists of well-drained RedYellow Podzolic soils developed in residuum from interbedded acid shales, siltstones, and sandstones. Texture of the deeper horizons is that of silty clay loam or silty clay.

Four units were mapped within the study areas and are described as follows:

Unit

83 B1

\section{Description}

Wellston silt loam, gently sloping phase (2-6 percent). This soil occupies gentle slopes, is well drained, and is strongly acid throughout the profile. 


\begin{tabular}{|c|c|c|c|}
\hline Unit & $\underset{\text { zon }}{\text { Hori- }}$ & $\begin{array}{l}\text { Depth } \\
\text { (inches) }\end{array}$ & on \\
\hline \multirow[t]{5}{*}{$\begin{array}{l}83 \mathrm{~B} 1- \\
\text { Con. }\end{array}$} & $\mathbf{A}_{\mathrm{D}}$ & $0-3$ & $\begin{array}{l}\text { Light-olive-brown }(2.5 Y 5 / 4) \text { friable } \\
\text { silt loam with fine granular struc- } \\
\text { ture. }\end{array}$ \\
\hline & $\mathbf{A}_{2}$ & $3-8$ & $\begin{array}{l}\text { Yellowish-brown (10YR 5/4) friable } \\
\text { silt loam with fine granular struc- } \\
\text { ture. }\end{array}$ \\
\hline & $B_{1}$ & $8-12$ & $\begin{array}{l}\text { Yellowish-brown }(10 Y R 5 / 6) \text { friable } \\
\text { to firm silt loam with weak fine } \\
\text { subangular blocky structure. }\end{array}$ \\
\hline & $\mathrm{B}_{2}$ & $12-26$ & $\begin{array}{l}\text { Strong-brown }(7.5 Y R 5 / 6) \text { firm silty } \\
\text { clay loam with medium subangular } \\
\text { blocky structure. }\end{array}$ \\
\hline & C & 26 & $\begin{array}{l}\text { Strong-brown (7.5YR 5/6) variegated } \\
\text { with yellowish-brown (10YR 5/6) } \\
\text { silty clay loam with medium sub- } \\
\text { angular blocky structure. }\end{array}$ \\
\hline $\begin{array}{l}3 \text { C1 } \\
3 \text { D1 }\end{array}$ & \multicolumn{3}{|c|}{$\begin{array}{l}\text { Wellston silt loam, sloping phase (6-12 percent). } \\
\text { Wellston silt loam, strongly sloping phase (12-20 } \\
\text { percent); it differs from the gently sloping phase in } \\
\text { having a slightly thinner solum. }\end{array}$} \\
\hline 83 D3 & \multicolumn{3}{|c|}{$\begin{array}{l}\text { Wellston silty clay loam, severely eroded strongly } \\
\text { sloping phase (12-20 percent); differs from the } \\
\text { gently sloping phase chiefly in having a silty-clay- } \\
\text { loam texture at the surface due to exposure of under- } \\
\text { lying layers to weathering during erosion. The } \\
\text { color at the surface is a little browner, also. }\end{array}$} \\
\hline
\end{tabular}

\section{MUSKINGUM BERIES}

The Muskingum series consists of lithosolic soils with weak horizons developed in residuum from interbedded acid sandstones, siltstones, and shales.

Seven units were mapped within the study areas and are described as follows:

\section{Unit Description}

$80 \mathrm{El}$ Muskingum silt loam, moderately steep phase (20-30 percent. This soil occupies moderately steep slopes, is well to excessively drained, and is medium to strongly acid throughout the profile. It is closely associated with the Wellston soils.

$\begin{array}{cc}\text { Hori- } \\ \mathrm{A}_{1} & \begin{array}{c}\text { Depth } \\ \text { (inches) }\end{array} \\ & 0-2\end{array}$

Dark-grayish-brown $(10 Y R \quad 4 / 2)$ friable silt loam with weak fine and medium granular structure.

$A_{2} \quad$ 2-8 Brown $(10 Y R$ 5/3) friable silt loam with weak fine platy or granular structure.

BC 8-18 Yellowish-brown (10YR 5/4) friable silt loam with a slightly higher clay content than $\mathrm{A}_{2}$ and weak fine subangular blocky structure.

D $18+$ Bedrock of acid sandstone, siltstone, and shale that is partially decomposed and commonly fractured in the upper part.

The profile may contain small stones and gravel throughout.

80 E3 Muskingum silt loam, severely eroded moderately steep phase (20-30 percent); it differs from the silt loam (moderately steep phase) chiefly by being severely eroded and by having a slightly lighter color and a thinner solum.
Unit

$80 \mathrm{Fl}$

$82 \mathrm{Dl}$

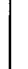




\section{STENDAL SERIES}

The Stendal series consists of somewhat poorly drained Alluvial soils derived from materials washed from soils underlain by acid sandstones, siltstones, and shales. One unit was mapped and is described as follows:

Unit

286

Unit

048

Unit

041

\section{Description}

Stendal fine sandy loam, local alluvium phase. This soil occupies nearly level slopes (0-4 percent), is somewhat poorly drained, and is strongly acid throughout the profile. Gravelly areas exist locally. Hori-
zon $\quad \begin{gathered}\text { Depth } \\ \text { (inches) }\end{gathered}$

$\mathrm{A}_{\mathrm{D}} \quad 0-2$ Dark-gray (10YR 4/1) very friable fine sandy loam with organic stain ${ }^{1}$ and weak granular structure.

$A_{p 2} \quad 2-8 \quad$ Light-brownish-gray $(10 Y R 6 / 2)$ very friable fine sandy loam with weak granular structure.

C 8-30+ Yellow (2.5Y 7/6) and yellowishbrown $(10 Y R 5 / 6)$ very friable fine sandy loam mottled light gray $(10 Y R$ 7/2), with weak granular structure.

GTONY COLLUVIAL LAND

Description

The stony colluvial land consists of undifferentiated talus material below the sandstone cliffs. The particle size of this material ranges from huge stones to clay. The size and quantity of stones prohibit use of the land for tillage or pasture; sufficient fine sandy loam occurs between the stones for good to excellent tree growth.

\section{STRIP-MINE SPOIL}

Description

The strip-mine spoil consists of mine spoil and the mine face. The spoil is disturbed material of acid sandstone, siltstone, and shale origin; in most areas it lies where it fell during the mining and has formed a large ridge with steep sides.

1 Both areas of the Stendal series were formerly cultivated but have been in grass for a period of time sufficient to develop an organic stain in the surface.

\section{CrIMATE *}

The climate of Kentucky is virtually continental in character, with rather wide extremes of temperature and precipitation. The winter cold waves are generally not severe, but in summer there are extended periods of hot sultry weather. The spring and fall months are generally pleasant.

The greater part of precipitation is due to the moisture-bearing low-pressure air masses which move from southwest to northeast from the western Gulf of Mexico. Warm, moist tropical air predominates during the summer months, and the relative humidity remains high during much of this season.

The temperature and precipitation data given here are based on the long-term records of the U.S. Weather

Adapted from Anderson, A. O., 1959, Climate of the States, Kentucky, in Climatology of the United States: U.S. Weather Bur., no. 60-15.
Bureau station at Williamsburg, Ky., about 18 miles southeast of the Beaver Creek basin.

The mean annual temperature at Williamsburg is $58^{\circ} \mathrm{F}$. July is generally the warmest month, with a mean temperature of $77^{\circ} \mathrm{F}$. Summer temperatures sometimes reach $100^{\circ} \mathrm{F}$ or higher. December is generally the coldest month, with a mean temperature of $40^{\circ} \mathrm{F}$. Minimum temperatures of $5^{\circ} \mathrm{F}$ or below can be expected during December, January, and February, but the number of days with such temperatures is small.

The mean annual precipitation at Williamsburg is 46 inches. Spring is generally the wettest season and fall is the driest. The mean monthly precipitation ranges from a high of 4.97 inches in March to a low of 2.15 inches in October.

Thunderstorms with high intensity rainfall are common during the spring and summer months. The number of days with thunderstorms each year ranges from 45 to 60 . Rainfall during these storms frequently amounts to 2 to 3 inches in a 24 -hour period.

The mean annual snowfall amounts to about 11 inches. Snow is common from November through March, but some has also occurred in October and April.

\section{HYDROLOGIC ENVIRONMENT'}

The movement, or circulation, of water is usually known as the hydrologic cycle. Several phases of this cycle, including precipitation, evapotranspiration, and runoff are of major importance in this study. Many factors affect the movement and quantity of water in each phase of the cycle. Several of the factors are interrelated and cannot be defined separately.

The streams in the Cane Branch, West Fork Cane Branch, and Helton Branch basins form dendritic and rectangular drainage patterns. The pattern that predominates depends on the texture and composition of the underlying beds and on the strike of the joint sets in the bedrock.

A dendritic drainage pattern predominates in areas of the less resistant claystones and siltstones that underlie the upper slopes of the Cane Branch and West Fork Cane Branch basins. Jointing is not abundant in these weaker rocks.

The upper slopes of the Helton Branch basin are underlain predominately by sandstone. A rectangular drainage pattern has formed along the joint sets of these more resistant beds.

The streams in the steep-walled valleys of the three basins have formed a rectangular drainage pattern

s Adapted from Nathan O. Thomas and Gerth E. Hendrickson, Louisville, Ky., and from George W. Whetstone, Columbus, Ohio (written communications), all of U.S. Geological Survey. 
in areas of the main eliff-forming sandstone. The direction of streamflow in these valleys is parallel to the strike of two prominent joint sets in the sandstone beds. Cane Branch and West Fork Cane Branch flow northwestward parallel to the northwest-striking joint set, and Helton Branch flows northeastward parallel to the northeast-striking joint set. The prominent tributaries in each basin also flow parallel to one of these joint sets.

Of the average 46 inches of precipitation that occurs annually in the area, about 20 to 25 inches is lost by evapotranspiration. Approximately half of this loss occurs during June, July, and August. The maximum monthly loss of about 4.5 inches generally occurs in July. The evapotranspiration is generally lowest during February when the average loss amounts to about 0.5 inch

Runoff in southeastern Kentucky averages about 22 inches annually from basins having drainage areas of 150 square miles or less. The monthly runoff varies greatly during the year. Runoff in February averages about 4.5 inches and is the highest; next in order of magnitude are runoff in March with about 4.0 inches and in January with about 3.5 inches. More than half of the annual runoff generally occurs during these 3 consecutive months. The month of lowest flow is generally October, with runoff averaging between 0.1 and 0.2 inch; in dry years, however, there may be no measurable runoff during September, October, or November.

Most floods occur during January, February, and March. Although the area is subjected to thunderstorms in the summer, the less intense winter storms contribute a greater total precipitation and usually produce the peak flow for the year.

Cane and Helton Branches are classed as perennial streams and rarely reach zero flow. The base flow (sustained or fair-weather runoff) of the two streams is about 0.1 and 0.2 cubic feet per second per square mile, respectively. The higher sustained flow of Helton Branch is due partly to three perennial springs in its upper reaches which feed water to the stream. The Cane Branch study area has no perennial springs. The Helton Branch study area has a larger proportionate area of soils with a greater water-storage capacity which also provides water for maintaining the base flow. Additional sources of base flow in each area are the water-bearing alluvial material and the water-bearing strata.

In the Beaver Creek area, as in most of the Eastern Coal Field, the boundaries of the ground-water drainage are approximately the same as the boundaries of the surface drainage. The slight dip of the beds and the orientation of fractures cause some variations in groundwater drainage, but the variations probably are small. The slow movement of water at great depth is independent of local topography and probably is not significantly affected by strip mining.

Water levels in observation wells and test holes indicate that shallow ground water moves from topographically high areas to discharge into streams, as is normal in humid regions; irregularities in the slope of the water table often indicate variations in the permeabilities of the underlying materials. The alternation of shaly and sandy beds in the strata above the main cliff-forming sandstone suggests that perched or semiperched ground water may be present here.

Ground water undoubtedly moves through both fractures and intergranular openings, but the relative amounts of water moving through the two types of openings have not been determined. The distinction may be of importance in the present study, because the water moving through fractures generally moves faster than that in intergranular openings, and, therefore, contamination from strip-mining operations would travel faster through the fracture openings.

Chemical weathering of the claystones and siltstones takes place through the processes of solution and chemical reaction. Reactions of water with the clay minerals brings about the gradual alteration of particles in the bedrock and supplies the surface and ground water with dissolved constituents for transport. Silica, calcium, magnesium, iron, aluminum, sulfate, and bicarbonate are the principal dissolved constituents that result from chemical alteration of the minerals present in the rocks.

Whereas chemical weathering has produced the gentle slopes in the uplands, frost action has been dominant in forming the steep valley walls along the canyons. The sandstones which make up the greater part of these steep walls are composed of about 96 percent quartz and do not weather as rapidly as the weaker claystones and siltstones underlying the uplands.

The deep canyons are always cooler than the surrounding uplands, and in winter they are embellished with tremendous quantities of ice. Water freezing along bedding planes and in joints exerts considerable force on the sandstone blocks and causes rock fragments of varying sizes, including some as large as a house, to be loosened and dropped onto nearby ledges and valley floors. In many places along the valley floors, these fragments form talus piles which are reworked and transported by the surface streams. 


\section{FOREST VEGETATION}

FOREST-COVER TYPES

The forest vegetation of the Helton Branch and Cane Branch study areas is similar to that found generally throughout the Cumberland region. It consists of stands of mixed pines or oaks in association with pine on the drier ridges and of mixed hardwoods commonly in association with hemlock in the coves and bottom lands. For this study, five distinct forest types are recognized. As defined by the U.S. Forest Service they are as follows:

Pine.-Pitch, short-leaf, and Virginia pines grow either in pure stands of single species or mixed and compose 50 percent or more of the stand. Generally associated with oaks, hickories, and minor species.

Hemlock.-Hemlock composes 50 percent or more of the stand. Associated with cove-type mixed hardwoods.

Mixed hardwoods.-Principal species include yellow poplar, elm, maple, basswood, and ash, which commonly grow in association with white oak or other oaks.

Oak-pine.-Pitch, short-leaf, and Virginia pines compose 25 to 50 percent of the stand and grow in association with various oaks. Scarlet oak generally grows on the drier ridges.

Oak-hickory.-Nearly pure stands of hardwoods are composed largely of various oaks and hickories.

The distribution of forest cover types in the Cane Branch, West Fork Cane Branch, and Helton Branch study areas is given in table 2, and the locations of these types are shown on plates 6 and 7 . For each forest type, three acres is the minimum size of stand recognized.

There are some differences in the percentages of the various forest-cover types in the Cane Branch and Helton Branch study areas, but the total percentages of forest-cover types, based on their environmental conditions, are very similar for both study areas.

TABLE 2.-Distribution of forest-cover types in Cane Branch, West Fork Cane Branch, and Helton Branch study areas

\begin{tabular}{|c|c|c|c|c|c|c|}
\hline \multirow{2}{*}{ Forest type } & \multicolumn{2}{|c|}{ Cane Branch } & \multicolumn{2}{|c|}{$\begin{array}{l}\text { West Fork } \\
\text { Cane Branch }\end{array}$} & \multicolumn{2}{|c|}{ Helton Branch } \\
\hline & Acres & Percent & Acres & Percent & Acres & Percent \\
\hline $\begin{array}{l}\text { Pine } \\
\text { Hemiock }\end{array}$ & 17 & 4 & - & & 11 & \\
\hline $\begin{array}{l}\text { Oak-pine } \\
\text { Oak-hickory }\end{array}$ & $\begin{array}{l}125-1 \\
86\end{array}$ & 20 & $\begin{array}{r}36- \\
127\end{array}$ & $\frac{22}{77}$ & $\begin{array}{r}16 \\
243 \\
27\end{array}$ & $\begin{array}{l}5 \\
5\end{array}$ \\
\hline $\begin{array}{l}\text { Mixed hardwoods } \\
\text { Open and stripped areas... }\end{array}$ & $\begin{array}{r}137 \\
64\end{array}$ & $\begin{array}{l}32 \\
15\end{array}$ & 2 & 1 & $\begin{array}{r}195 \\
49\end{array}$ & 96 \\
\hline Total...... & 429 & 100 & 165 & 100 & 541 & 100 \\
\hline
\end{tabular}

Forest of pine, oak-pinè, and oak-hickory, representing the sites of shallower and drier soil, covers 52 percent of the Helton Branch area and 53 percent of

\footnotetext{
'Adapted from Malcom J. Williamson, Berea, Ky., and Norman R. Tripp, Upper
Darby, $\mathrm{Pa}$. (written communications),
}

the Cane Branch area. Forest of hemlock and mixed hardwood types, representing the sites of deeper and more moist soil, covers 39 percent of the Helton Branch area and 32 percent of the Cane Branch area. The somewhat smaller percentage of hemlock and mixed hardwoods in the Cane Branch area may be, in part, due to strip mining and land clearing, which have taken place in this zone of trees, and, in part, to the larger area of deep northward-facing coves in the Helton Branch area, which are conducive to better growth of the hemlock and mixed hardwood types.

Each forest type has been divided into stand-size classes of poles, small sawtimber, and large sawtimber. Poles are defined as trees 5 to 11 inches d.b.h. (diameter breast high), small sawtimber as trees 12 to 16 inches d.b.h., and large sawtimber as trees more than 16 inches d.b.h. The distribution and acreage of these stand-size classes are given in tables 3 and 4.

\section{STOCKING DENSITY}

The number of trees per unit area is known as the stocking density and is sometimes expressed as "basal area per acre" (the number of square feet of space occupied by tree stems). Table 5 lists the stocking density for the Cane Branch and Helton Branch study areas. The greater basal area in the Helton Branch study area, even though there is a higher percentage of small trees (tables 3 and 4), shows that this study area has a larger number of stems per acre than the Cane Branch study area. Neither study area shows what would be considered adequate stocking for forest-management purposes.

TABLE 3.-Distribution of stand-size classes in Cane Branch, West Fork Cane Branch, and Helton Branch study areas

\begin{tabular}{|c|c|c|c|c|c|c|}
\hline \multirow{2}{*}{ Stand-size class } & \multicolumn{2}{|c|}{ Cane Branch } & \multicolumn{2}{|c|}{$\begin{array}{c}\text { West Fork } \\
\text { Cane Branch }\end{array}$} & \multicolumn{2}{|c|}{ Helton Branch } \\
\hline & Acres & Percent & Acres & Percent & Acres & Percent \\
\hline $\begin{array}{l}\text { Poles } \\
\text { Small sawtimber- } \\
\text { Large sawtimber. }\end{array}$ & $\begin{array}{r}77 \\
288\end{array}$ & $\begin{array}{l}21 \\
79\end{array}$ & $\begin{array}{r}49 \\
114\end{array}$ & $\begin{array}{l}30 \\
\mathbf{7 0}\end{array}$ & $\begin{array}{r}152 \\
324 \\
16 \\
\end{array}$ & $\begin{array}{r}31 \\
66 \\
3 \\
\end{array}$ \\
\hline Total...... & 365 & 100 & 163 & 100 & 492 & 100 \\
\hline
\end{tabular}

TABLE 4.-Acres of stand-size classes by forest-cover types in Cane Branch, West Fork Cane Branch, and Helton Branch study areas

\begin{tabular}{|c|c|c|c|c|c|c|c|}
\hline \multirow{2}{*}{ Forest-cover type } & \multicolumn{2}{|c|}{ Cane Branch } & \multicolumn{2}{|c|}{$\begin{array}{l}\text { West Fork } \\
\text { Cane Branch }\end{array}$} & \multicolumn{3}{|c|}{ Helton Branch } \\
\hline & Poles & $\left|\begin{array}{c}\text { Small } \\
\text { saw- } \\
\text { timber }\end{array}\right|$ & Poles & $\begin{array}{c}\text { Small } \\
\text { saw- } \\
\text { timber }\end{array}$ & Poles & $\begin{array}{l}\text { Small } \\
\text { saw- } \\
\text { timber }\end{array}$ & $\begin{array}{c}\text { Large } \\
\text { saw- } \\
\text { timber }\end{array}$ \\
\hline ne & 17 & & & & & 11 & 16 \\
\hline $\begin{array}{l}\text { Hem-pine-. } \\
\text { Oak-pinekry.-. } \\
\text { Mixed hardwoods }\end{array}$ & $\begin{array}{r}8 \\
52\end{array}$ & $\begin{array}{r}-125 \\
78 \\
85\end{array}$ & $\begin{array}{l}136 \\
33\end{array}$ & $\begin{array}{l}139 \\
95\end{array}$ & $\begin{array}{r}-135 \\
17\end{array}$ & $\begin{array}{r}107 \\
10 \\
196\end{array}$ & (10 \\
\hline Total. & 77 & 288 & $49^{\circ}$ & 114 & 152 & 324 & 16 \\
\hline
\end{tabular}


TABLE 5.-Stocking density in Cane Branch and Helton Branch study areas

\begin{tabular}{|c|c|c|}
\hline \multirow{2}{*}{ Forest-cover type } & \multicolumn{2}{|c|}{ Basal area per acre (sq ft) } \\
\hline & $\begin{array}{c}\text { Cane } \\
\text { Branch 1 }\end{array}$ & $\begin{array}{l}\text { Helton } \\
\text { Branch }\end{array}$ \\
\hline $\begin{array}{l}\text { Pine } \\
\text { Hemmock } \\
\text { Oak-pine } \\
\text { Oak-hickory } \\
\text { Mixed hardwoods }\end{array}$ & $\begin{array}{r}94.0 \\
69.0 \\
50.2 \\
65.2\end{array}$ & $\begin{array}{l}65.0 \\
77.5 \\
78.1 \\
57.0 \\
78.5\end{array}$ \\
\hline A verage (weighted by area) & 61.4 & 76.8 \\
\hline
\end{tabular}

1 Includes the West Fork Cane Branch study area.

\section{MINING HISTORY AND METHODS ?}

There have been several phases of coal prospecting and mining in the Cane Branch and West Fork Cane Branch study areas. Most of this activity has taken place in the Cane Branch area, and all the coal mined in this locality has been taken from the Barren Fork coal seam. Prospecting has been the major activity in the West Fork Cane Branch area. There has been no prospecting nor mining in the Helton Branch area.

In the Cane Branch area two methods of coal mining have been used. The principal method has been strip mining, which is the removal of the overburden and the coal by equipment operated on the surface. Most of the coal from this area has been mined by this method. Only a minor amount of coal has been removed from the Cane Branch area by drift mining, which consists of driving a tunnel, or drift, into an exposed coal seam in a hillside and removing the coal with equipment operated under the surface.

\section{MINING BEFORE 1955}

Before 1955, coal mining in the Cane Branch area was done only on a small scale and had little relation to the effects caused by the large-scale operations which began in 1955. Mining before 1955 is outlined here as background information.

During the 1930's a drift mine was opened and worked on the southwest side of the Cane Branch area (pl. 3). This drift mine extended into the coal seam for about 200 feet. The mine was abandoned around 1940, and it was badly caved when examined in 1955 .

In the spring of 1947, approximately 1 acre in the southern part of the Cane Branch area was stripped of the Barren Fork coal seam (pl. 3). The details of this mining operation are not known. The coal in the high wall is now covered by the pool of water in the small strip pit, and the accompanying spoil bank is partly covered by vegetation.

\footnotetext{
'Adapted from James J. Dowd (written communication), Research Director
} Coal Mining Research Center, U.S. Bureau of Mines, region V, Pittsburgh, Pa.

\section{MINING AFTHR 1966}

From 1955 to 1960 , four different mining operators carried on prospecting and mining activities in the Cane Branch and West Fork Cane Branch areas. The following history of mining outlines these activities.

\section{ACTIVITIES OF THE FIRST OPERATOR (1955-66)}

In 1955, a mining operator leased 85 acres of land in parts of the Cane Branch and West Fork Cane Branch areas. In accordance with the Kentucky mining laws, the operator paid the Kentucky Division of Strip Mining and Reclamation the required permit fee of $\$ 50$ plus $\$ 10$ for each acre of land to be affected by stripping, and he posted a bond of $\$ 500$ to insure reclamation of the land as specified by the State law.

To prospect for the coal seam, the operator sank a diamond-drill hole at the north end of his lease, but the hole was abandoned when the drill encountered hard sandstone at a depth of 40 feet. A trench cut by bulldozer about 800 feet north of the abandoned drift mine exposed the coal seam (pl. 3). The coal seam, where stripped, comprised two benches separated by a carbonaceous shale parting. A description of an average section of the coal seam follows:

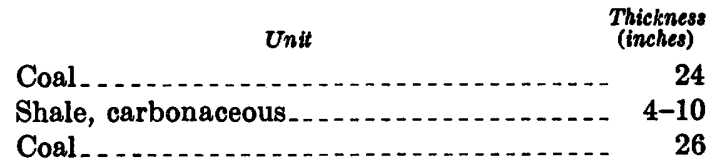

The following equipment was used at this mine: one 11/2-cubic-yard standard front-stripping shovel; one $\% / 4$ cubic-yard coal-loading shovel; two bulldozers with front-angle blade; one 16-cubic-yard carryall pan; one highwall overburden drill; one patrol grader; six 11/2-ton dump trucks.

The equipment was moved into the mining area over a dirt road. This road was graded and kept in a passable condition for moving supplies to the pit and to haul mined coal from the pit. In addition, access roads connecting coal-loading points in the pit with the dirt road were made and maintained. All maintenance and new road work were done by the mining company.

Strip mining began May 28, 1955, in the vicinity of the bulldozed trench at the north end of the leased property. The first cut uncovered an area of coal 40 to 50 feet wide. Because the terrain was hilly, stripping was done by the contour method. The stripping shovel followed the outcrop, and the spoil was deposited outside of the strip pit on undisturbed ground.

Horizontal holes were drilled in the highwall about 6 to 12 inches above the coal, and the rock was fragmented by blasting. The blasting also loosened the coal, and therefore no drilling or blasting was needed in the coal seam before loading. 
Where there were short inward bends or curves in the coal outcrop, all spoil could not be cast to clear the uncovered coal, and the pit became "dirt-bound." The carryall pan then was used to load and haul the excess spoil from the pit in such areas. Occasionally, the carryall pan, pulled by a bulldozer, was used on the highwall to load and dispose of unconsolidated material so that the capacity of the stripping shovel would not be exceeded: This method permitted some coal under as much as 40 feet of cover to be mined.

Coal loading began after the first cut had been advanced a few hundred feet. The small amount of waste material on the top bench of the coal seam was cleaned off with a grader, a bulldozer, and by men using shovels and brooms. Any spoil that fell back onto the uncovered coal was loaded by the carryali pan and hauled away. After cleaning, the top bench of coal was loaded by the $3 / 4$-cubic-yard loading shovel into trucks and hauled from the pit. The shale parting between the benches was then removed by the grader and a bulldozer. After the parting was removed, the bottom bench of coal was loaded. The extreme care used in cleaning the waste material from the top bench and in removing the parting accounts for the fact that the mined coal averaged less than 8 percent ash.

The first cut was never advanced more than 600 to 800 feet ahead of the second cut. While the coal from the first cut was being loaded, the stripping shovel was sent back to start the second cut. Spoil from this cut was cast into the pit where coal from the first cut had been mined. Generally, after two cuts were made the overburden became too thick for the stripping shovel to be used economically. The height of the highwall of the pit, when mining was stopped, ranged from 25 to 40 feet.

Strip mining was ended on April 7, 1956, because the coal seam became too thin to mine profitably. Near the south end of the leased property the coal benches were thinner and the parting thicker. At the north end the coal seam finally pinched out. Several prospect trenches bulldozed in the fall of 1955 near the north end of the leased property in the Cane Branch and the West Fork Cane Branch areas (pl. 3) had failed to show a continuation of the coal seam.

The operator had planned to auger mine some of the coal from the highwall, but he then decided against this plan because of the excessive wear on cutting bits that would be caused by the iron sulfides in the coal seam.

During 10 months of strip mining, 38,899 tons of coal were mined. The entire production was used as steam coal, principally by the Georgia Power Co. A composite analysis, in percent, by the Georgia Power
Co. of the last 15 cars of coal shipped from the mine follows:

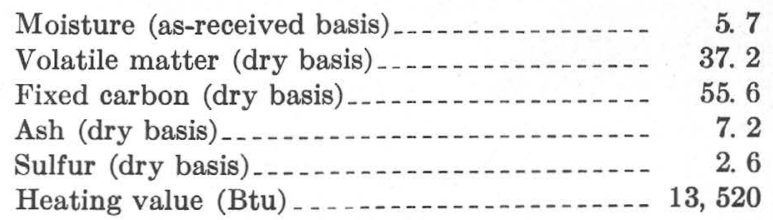

At the request of the Work Group Committee for this study, the reclamation work was not done immediately after strip mining was ended. Water therefore accumulated in many parts of the abandoned strip pit and nearly covered the coal exposed in the highwall.

The reclamation work was done between June 8 and June 15, 1956, about 2 months after strip mining ended. The spoil bank was leveled by a bulldozer and the patrol grader. Those parts of the pit that did not contain water were covered with spoil by the operator. Sections of the coal seam adjacent to the pools were still exposed above the water level when the reclamation work had been completed. Two drainage ditches near the central part of the spoil bank were cleared to allow seepage to flow from the strip pit to Cane Branch.

Figure 12 is a general view of the highwall and the spoil bank as they appeared in 1958. The trough in the spoil bank shown in the center of the figure is one of the two drainage ditches that was cleared at the completion of the mining operations. The top of the spoil bank is relatively level. After completion of the reclamation work, the operator applied for and received the bond he had filed with the Kentucky Division of Strip Mining and Reclamation to insure reclamation of the land.

In the months after the reclamation work, many sections of the highwall slumped and caused partial filling of the pit and covering of the coal seam. By July 1957 , the entire coal seam was covered with water and (or) spoil.

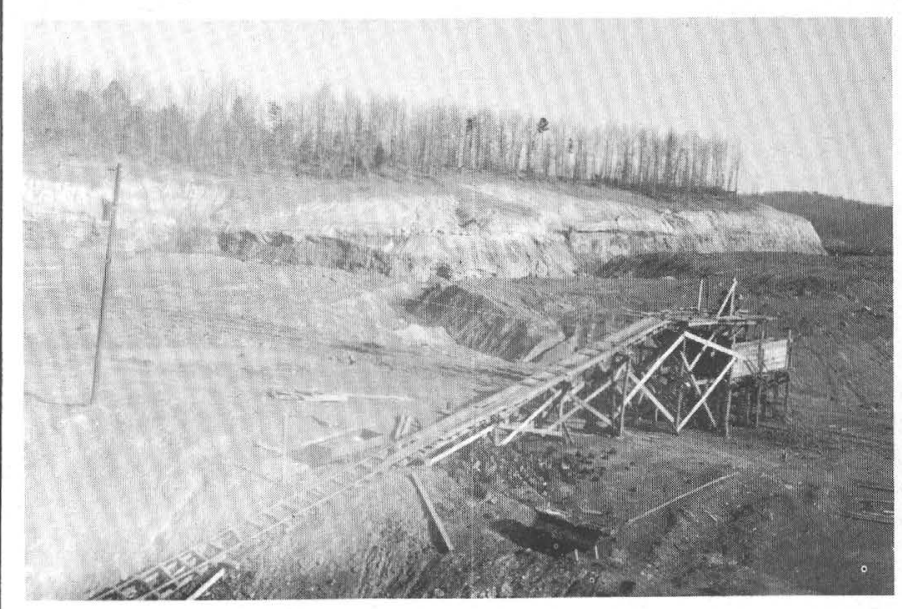

FIGURE 12.-View of the highwall, spoil bank with drainage ditch, and tipple on the southwest side of the Cane Branch area in 1958. 
On January 15, 1958, the spoil bank was seeded by the Kentucky Reclamation Association with a mixture of grass seeds commonly used on banks at the request of the Kentucky Division of strip mining and reclamation. A few plants became established on the hardpacked shale of the bank.

The mining and reclamation procedures just described are similar to the procedures followed in most strip mines in eastern Kentucky, but they differ from other procedures in that the reclamation work was not completed immediately after mining was ended. The 2 -month delay between the end of mining and the leveling of the spoil bank allowed the coal face to weather longer than usual. Also, the coal seam was not entirely covered with spoil in the usual manner.

\section{ACTIVITIES OF THE SECOND OPERATOR (1957-59)}

In October 1957, a second mining operator leased 50 acres of land along the southwest side of the Cane Branch area in the vicinity of the mining locality described previously. A drift was started into the Barren Fork coal seam at the base of the highwall about 400 feet south of the original drift mine (pl. 3). Throughout the period of operations, acid water was pumped several times a day from the mine into one of the drainage ditches cutting through the spoil bank. On many days over 2,000 gallons of water were pumped from the mine.

The mining consisted of drilling and blasting the coal, loading the coal into a mine car, hoisting the car up an incline, and dumping the coal into a storage bin for subsequent truck loading. The incline and storage bin are shown in figure 12.

This mine was abandoned in January 1959. The total length of the drift was approximately 175 feet. Water accumulated in the abandoned drift, and seepage from the drift during the winter of 1959-60 averaged about 180 gallons per day.

\section{ACTIVITIES OF THE THIRD OPERATOR (1958-59)}

In the summer of 1958, a third mining operator began to strip mine the Barren Fork coal seam in the Freeman Fork basin, which lies to the east of the Cane Branch area.

During September 1958, the operator strip mined around the divide between the two basins and began operations along the northeast side of the Cane Branch study area (pl. 3). Within a few weeks the coal was removed from 4 acres of the study area and the spoil bank resulting from the operation was graded. The strip pit that resulted from the mining quickly filled with water after it was abandoned. A drainage ditch was cut through the spoil bank from one section of this pit to allow water to overflow into a small tributary of Cane Branch.
On October 28, 1958, the third operator began prospecting in the Cane Branch study area by cutting a drainage ditch through the north end of the spoil bank on the southwest side of the valley to allow the water in the northernmost pit to drain off. He was planning to strip mine along the southwest side of the valley.

The operator, however, abandoned this plan and, instead, leased land along the northeast side of the study area. He began strip mining there about December 1, 1958 (pl. 3). The operator began contour stripping the Barren Fork coal seam at the east end of the lease and proceeded westward along the hillside. By April 1959, the first cut had been removed along the entire extent of the area shown in plate 3. Figure 13 shows the mine-stripping operation in progress. The bench in the lower part of the figure is the Barren

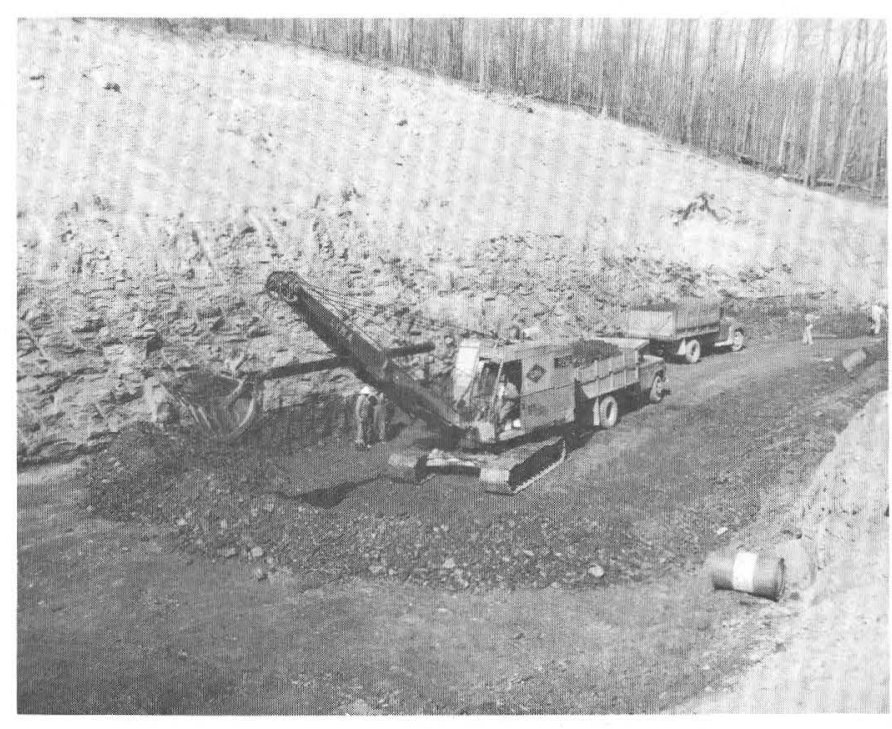

FigURE 13.-Strip-mining operation along the northeast side of the Cane Branch area.

Fork coal seam as it appeared after the overburden had been removed. The shovel is removing the coal from the seam and is loading it into the nearby truck.

Figure 14 shows another section of the strip pit after the coal seam had been removed. A pool of water is beginning to form in the pit. The dark layer at the base of the highwall on the left side of the photograph is the coal seam. The heterogeneous mixture of rock removed from the hillside forms the spoil bank on the right side of the photograph.

When the coal seam in the western part of the leased area became too thin to mine profitably, the operator began to make additional cuts along the newly-formed highwall. From April to August 1959, a second cut and in some places a third cut was made in the hillside. Strip mining was ended August 3, 1959, when the overburden in the highwall finally became too thick to mine the coal economically. 


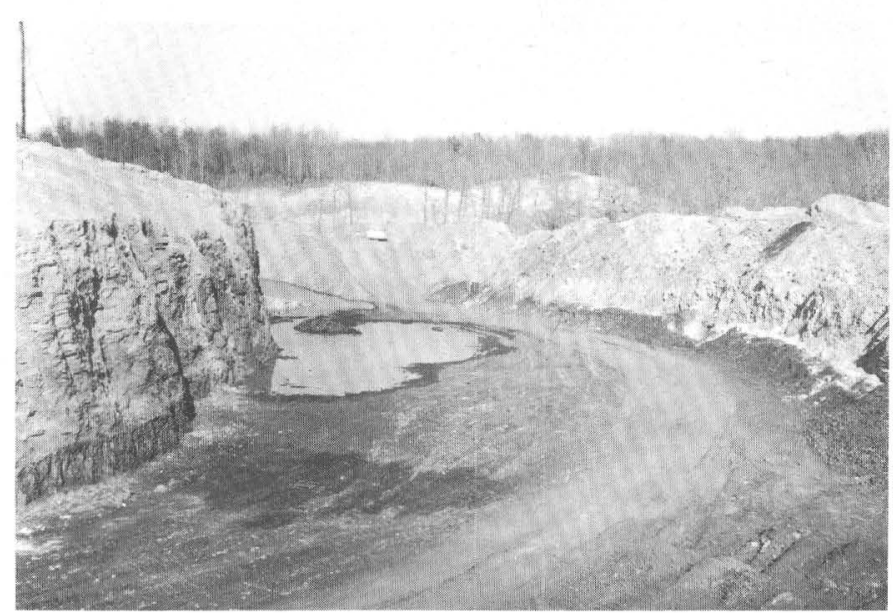

Figure 14.-View of the highwall, strip pit, and spoil bank after the first cut of coal had been removed from the northeast side of the Cane Branch area.

The reclamation work was done from August 3 to 6,1959 . The spoil bank was graded, and the pools of water in the pit were ringed with spoil to prevent free drainage. The drainage ditch for the easternmost part of the pit was cleared to prevent the formation of a pool. Water moving through this drainage ditch flows into a tributary of Cane Branch.

In the eastern part of the strip-mined area the operator covered the coal seam with spoil, but along the rest of the strip pit only scattered parts of the coal seam were covered with spoil. Much of the lower part of the coal seam was covered by the pools of water in the strip pit, but the upper part of the seam was still exposed when the reclamation work was completed.

By March 1960, some parts of the highwall had slumped to cover previously exposed portions of the coal seam, but in many places the upper part of the seam was still exposed.

\section{ACTIVITIES OF THE FOURTH OPERATOR (1960)}

On February 3, 1960, a fourth mining operator began prospecting for coal in the West Fork Cane Branch basin near the area where prospect trenches had been dug in the fall of 1955 (pl. 3). A small spoil bank resulted from the removal of the trees, soils, and bedrock from about 1.5 acres. The coal seam uncovered was not thick enough to mine profitably, so on February 9 the operator began prospecting across the divide in the Cane Branch study area (pl. 3).

Again, he was unable to locate coal of minable thickness. On March 14, 1960, he piled spoil around the prospect pits which had filled with water and removed his equipment from the area.

Thus, in the period from April 1955 to March 1960, four different mining operators disturbed the natural environment of the Cane and West Fork Cane Branch study areas by mining and prospecting. 
